\title{
Checklist of the vascular flora of a portion of the hyper-humid region of La Chinantla, Northern Oaxaca Range, Mexico
}

\section{creative commons}

Botanical Sciences 95 (4): 722-759, 2017

DOI: $10.17129 /$ botsci.1812

Received:

August 15th, 2017

Accepted:

October 2nd, 2017

Associated Editor:

Juan Núñez Farfán

Copyright: (c) 2017 Meave et al This is an open access article distributed under the terms of the Creative Commons Attribution License, which permits unrestricted use, distribution, and reproduction in any medium, provided the original author and source are credited.

${ }^{1}$ Departamento de Ecología y Recursos Naturales, Facultad de Ciencias, Universidad Nacional Autónoma de México, Ciudad de México 04510, Mexico.

${ }^{2}$ Instituto de Investigaciones en Ecosistemas y Sustentabilidad, Universidad Nacional Autónoma de México, Morelia 58190, Michoacán, Mexico.

${ }^{3}$ Present address: Instituto de Ecología, A.C., Carretera Antigua a Coatepec 351, El Haya, Xalapa 91070, Veracruz, Mexico.

* Corresponding author: jorge. meave@ciencias.unam.mx
Jorge A. Meave ${ }^{1 *}$, Armando Rincón-Gutiérrez ${ }^{1}$, Guillermo IbarraManríquez ${ }^{2}$, Claudia Gallardo-Hernández ${ }^{1,3}$ and Marco Antonio ROMERO-ROMERO ${ }^{1}$

\section{Abstract}

Background: La Chinantla, a topographically and geomorphologically complex region, and probably the most humid in the country, hosts a diverse but largely unknown biota, particularly at higher elevations.

Questions: How many plant species are present in La Chinantla? How are these species distributed along the elevational gradient encompassed in the region?

Studied species: Lycopodiophyta, Pteridophyta, Gimnospermopsida, Magnoliidae, Eudicots, Monocots.

Study sites and years of study: We studied the flora of the La Chinantla hyper-humid region, Northern Oaxaca Range, southern Mexico, from 1993 to 2017.

Methods: We collected 2,654 specimens in 73 main localities distributed across an elevational range from 250 to 3,020 $\mathrm{m}$ (but concentrated above $800 \mathrm{~m}$ ). Numerous experts in plant taxonomy examined the specimens and provided or confirmed identifications.

Results: The checklist of the vascular plants includes 1,021 species, 471 genera and 162 families of vascular plants. The specimens/species ratio (2.6) reflected a satisfactory collecting effort. The most diverse families were Asteraceae, Rubiaceae, and Orchidaceae, whereas the most speciose genera were Peperomia, Miconia and Piper. Most listed species are herbs $(47.3 \%$ of the total) and trees $(35.2 \%)$, whereas the terrestrial $(85.4 \%)$ and epiphytic $(15.9 \%)$ growth habits were the most frequent ones (some species presented more than one growth form or growth habit category).

Conclusions: Based on the magnitude of the current checklist, we estimate that the actual number of species in this region must be around 1,650. The recorded richness of vascular plant species of La Chinantla confirms the large diversity and uniqueness of its flora and calls for efficient conservations efforts to ensure its maintenance in the future.

Key words: cloud forest, floristics, lower montane forest, plant growth form, tropical rain forest, upper montane forest.

\section{Lista de la flora vascular de una porción de la región hiperhúmeda de La Chinan- tla, Sierra Norte de Oaxaca, México}

\section{Resumen}

Antecedentes: La Chinantla, una región compleja en su topografía y geomorfología, y probablemente la más húmeda en el país, alberga una biota diversa pero desconocida en gran medida, particularmente en las partes altas del gradiente altitudinal.

Preguntas: ¿Cuántas especies de plantas están presentes en La Chinantla? ¿Cómo se distribuyen estas especies a lo largo del gradiente altitudinal?

Especies estudiadas: Lycopodiophyta, Pteridophyta, Gimnospermopsida, Magnoliidae, Eudicotiledóneas, Monocotiledóneas.

Sitio de estudio y fechas: Estudiamos la flora de la región hiperhúmeda de La Chinantla, Sierra Norte de Oaxaca, sur de México, de 1993 a 2017.

Métodos: Recolectamos 2,654 especímenes en 73 localidades principales distribuidas a través de un intervalo altitudinal de 250 a 3,020 m (con énfasis arriba de la cota de 800 m). Numerosos taxónomos expertos examinaron los especímenes y proporcionaron o confirmaron las determinaciones.

Resultados: La lista de plantas vasculares incluye 1,021 especies, 471 géneros y 162 familias de plantas vasculares El cociente especímenes/especies (2.6) reflejó un esfuerzo de colecta satisfactorio. Las familias más diversas fueron Asteraceae, Rubiaceae y Orchidaceae, mientras que los géneros más ricos en especies fueron Peperomia, Miconia y Piper. La mayoría de las especies en la lista son hierbas (47.3\% del total) y árboles (35.2\%), mientras que los hábitos de crecimiento terrestre $(85.4 \%$ ) y epífito (15.9\%) fueron los más frecuentes (algunas especies presentaron más de una forma o un hábito de crecimiento).

Conclusiones: Con base en la magnitud de esta lista florística, podemos estimar que el número real de especies presentes en la región debe de ser de alrededor de 1,650. La riqueza de plantas vasculares registrada en La Chinantla confirma la gran diversidad y el carácter único de su flora, y señala la necesidad de hacer esfuerzos de conservación eficientes para asegurar su mantenimiento en el futuro.

Palabras clave: bosque montano alto, bosque montano bajo, bosque nublado, bosque tropical lluvioso, forma de crecimiento, florística, hábito de crecimiento. 


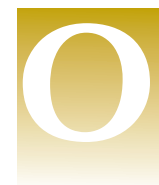

axaca, one of the culturally and biologically most distinctive states of Mexico, hosts an unusually large proportion of the plant diversity occurring in this country. With precise documented figures of 8,903 (García-Mendoza \& Meave 2011) and 10,229 (Villaseñor 2016) species of vascular plants, this state's flora only rivals with neighboring Chiapas, whose estimated richness ranges between $8,250-10,000$ species, and exceeds estimated figures for other adjacent states like Guerrero (6,500-7,000 species) and Veracruz (8,000-8,500 species) (García-Mendoza 2004, González-Espinosa et al. 2005, Krömer et al. 2010, Villaseñor 2016). Many factors contribute to this high-order diversity. One of the most widely accepted is the highly complex topography of Oaxaca's territory (Lorence \& García-Mendoza 1989). The presence of deep valleys, isolated mountain peaks, regions of very high humidity almost adjacent to others where water is rather scarce, offer an extraordinary gamut of ecological scenarios for the evolution of lineages adapted to different climatic settings (see García-Mendoza [2004] for an extensive analysis of the state's flora and its study). Indeed, the geo-climatic history of mountains of Mexico is deemed responsible for the intense diversification of many plant groups (e.g., Perry 1991, Rzedowski 1991, Nixon 1993, Villaseñor et al. 1998, Valencia-Ávalos \& Nixon 2004).

A striking feature of the topography of Oaxaca's territory is the massive and complex mountain formation located on its northern part. These mountains, collectively known as Northern Oaxaca Range (Sierra Norte de Oaxaca), actually form part of the Sierra Madre del Sur Physiographic Province, an extensive mountain complex that occupies much of southern Mexico (Ferrusquía-Villafranca 1993, Centeno-García 2004). Due to its NW-SE orientation, the Northern Oaxaca Range acts as a barrier that obstructs the movement of the moisture-laden Easterlies blowing from the Gulf of Mexico. Thus, on their leeward slopes most of the water transported inland is discharged, rendering this region the rainiest in the country and warranting its classification as hyper-humid (Shen \& Chen 2010). The combination of this very high precipitation with an extremely rough topography, two efficient deterrents of human activities, likely explains why the Northern Oaxaca Range still hosts extensive tracts of very well-preserved forest. Such good conservation status has been more or less compatible with a relatively large population of native people, among which the Chinantec ethnic group is noteworthy, as they inhabit the most inaccessible and hard for human livelihood area of this region (Martin \& Madrid 1992).

Expectedly, a region with such characteristics should host a very large biological diversity. However, efforts to inventory its plant component have been few and generally very localized. At the end of the first half of the 20th century the first accounts related to the flora of the Chinantec region were published (Reko 1949, Paray 1951, Matuda 1959). Later, the rise of the pharmaceutical industry centered on the production of contraceptives based on barbasco (Dioscorea composita Hemsl., Dioscoreaceae) attracted to the region research groups that pioneered the tropical ecological research in the country (Tamayo \& Beltrán 1977 and papers therein). Such work concentrated on the study of lowland primary and secondary forests (Gómez-Pompa et al. 1964, Sousa-Sánchez 1964, SarukhánKermez 1968). Yet, the flora typical of high-elevation forests remained largely unknown for years, until the construction of Highway 175 that connected Tuxtepec with Oaxaca City, the state's capital. In the last three decades of the 20th century numerous botanists explored the region; regrettably, their findings were seldom published (e.g., Lorence \& Torres-Colín 1988, Martin \& Madrid 1992, Meave et al. 1996, Gallardo et al. 1998, Ibarra-Manríquez \& Mendoza 2003). Some floristic studies were conducted alongside the study of vegetation (Boyle 1996, Arellanes-Cancino 2000, Romero-Romero et al.2000). Two particularly important contributions to the knowledge of this region's flora are the works of Rzedowski \& Palacios-Chávez (1977) and Torres-Colín et al. (2009).

In this paper we report an initial floristic checklist of a relatively small but extraordinarily well-preserved portion of the Northern Oaxaca Range. This checklist results from an intense and systematic effort that concentrated mostly on undisturbed forests located in the 800-3,020 $\mathrm{m}$ a.s.l. range, although it also includes species collected at lower elevations and some areas of secondary vegetation derived from human activities.

\section{Materials and methods}

Study region. The study area is located in northern Oaxaca State, Mexico, and forms part of La Chinantla, a culturally defined region that roughly corresponds with the geographical range of 
Figure 1. Map showing the approximate extent of the area covered by the floristic survey in La Chinantla region, Northern Oaxaca Range (Oaxaca State), southern Mexico. The red dots show the location of the 73 main localities where plant collections were done. Gray lines are 1,000 m contour lines; elevation of the highest regional peak (Cerro Pelón) is also shown. Main tributaries of the Papaloapan river are shown in blue; paved roads are shown in brown. the Chinantec ethnic group (Meave et al. 2006). Our botanical exploration took place mainly in the Perfume River basin, a low-order tributary of the Papaloapan River, near the village of Santa Cruz Tepetotutla, San Felipe Usila municipio (municipio is a second-order territorial unit sometimes translated as municipality but more closely equivalent to a county in other countries). Additional botanical expeditions were conducted around Nueva Santa Flora and Cerro Verde, in the same municipio, as well as in the surroundings of Arroyo Seco and Cerro Mirador (Valle Nacional municipio), and of La Esperanza and Cerro Pelón (Santiago Comaltepec municipio). Extreme coordinates encompassing all these localities are $17^{\circ} 35^{\prime} 10^{\prime \prime}$ to $17^{\circ} 59^{\prime} 30^{\prime}$ ' $\mathrm{N}$, and $96^{\circ}$ 18 ' $30^{\prime \prime}$ to $96^{\circ} 34^{\prime} 43$ " W (INEGI 2017; Figure 1). The area explored during the botanical survey is approximately $265 \mathrm{~km}^{2}$ in size.

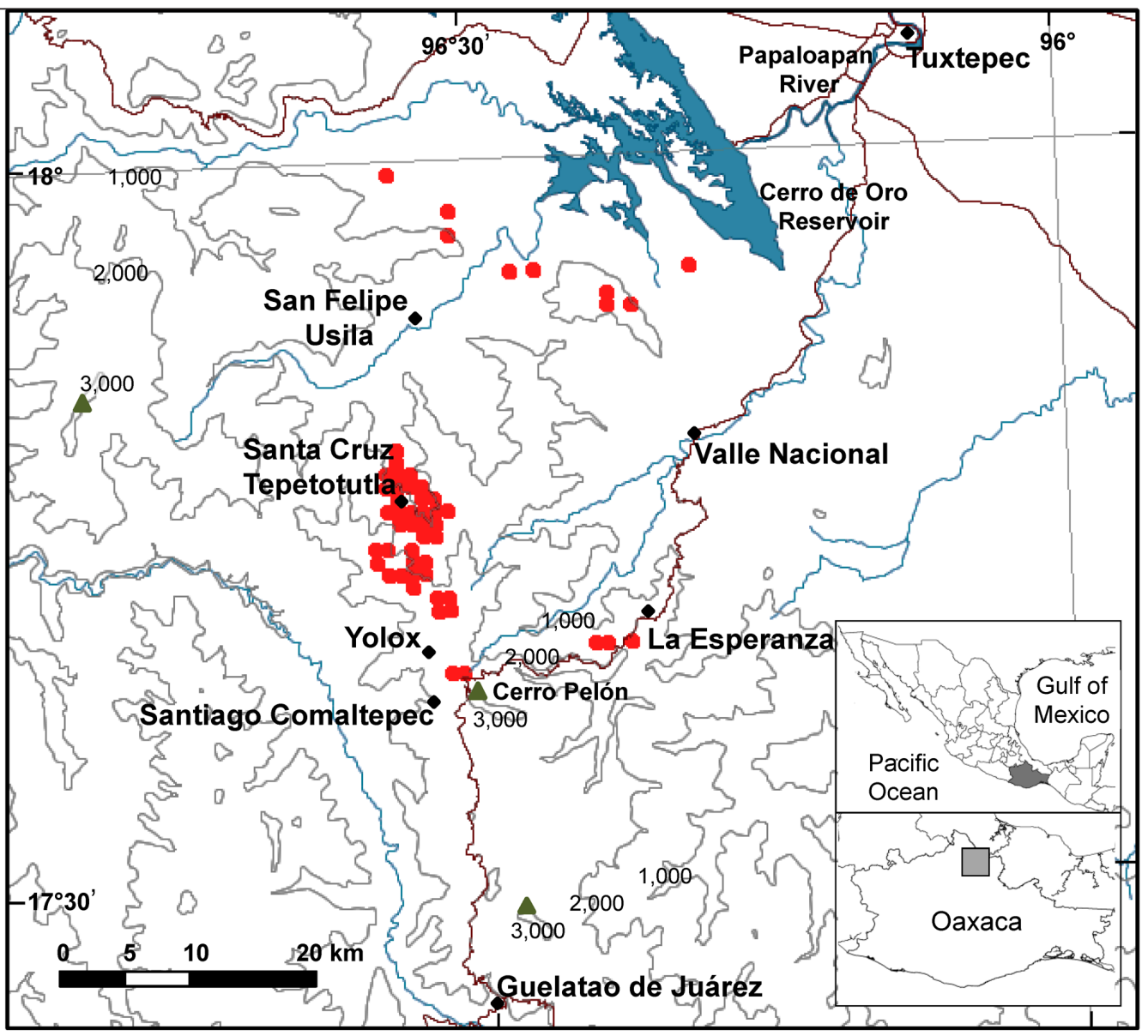

The uplifting of the Northern Oaxaca Range began around 14 Ma ago (Centeno-García 2004). This mountain range limits to the North with the Gulf of Mexico Coastal Plain, and from there it raises abruptly from almost sea level to $c a .3,200 \mathrm{~m}$; more than 120 mountain tops are located above $2,500 \mathrm{~m}$. The terrain is typically very steep, with around $45 \%$ of the land having slopes between $18^{\circ}$ and $45^{\circ}$ or more (Ortiz-Pérez et al. 2004), which explains why massive landslides are common. Such steepness is readily perceived along the road connecting Valle Nacional (65 $\mathrm{m})$ with the top of Humo Chico Mountain $(3,200 \mathrm{~m})$, two locations only ca. $30 \mathrm{~km}$ apart on the horizontal plane.

Lithosol is the prevailing soil type in the region (Alfaro 2004). The few studies on the regional soils emphasize their overall shallowness, but soils are highly heterogeneous regarding fertility, from those with relatively high organic matter contents to very infertile Oxisols (van der Wal 1996, 1998), which appears to be related to the presence of different parent materials. Main pedogenic processes occurring in the region are humus accumulation, in situ weathering, podzolization, and iron reduction due to water stagnation in mineral topsoil (Álvarez-Arteaga et al. 2008). 
The climate of La Chinantla is highly variable, mostly owing to the large elevational gradient. Unfortunately, the scarcity of weather stations precludes detailed description of the regional climate. Between May and October the moisture-laden Trade Winds enter the Mexican territory from the Gulf of Mexico, resulting in a well-marked rainy season in the summer months. The adiabatic cooling of the air masses as they are forced to climb the Northern Oaxaca Range produces intense rainfall, particularly at middle elevations. Examples of this humped-shaped variation are the following localities: at Valle Nacional $(65 \mathrm{~m})$ annual precipitation is 3,590 mm; further up, at Vista Hermosa $(1,450 \mathrm{~m})$ annual rainfall is $5,956 \mathrm{~mm}$, whereas at the high-elevation locality of Humo Chico $(3,240 \mathrm{~m})$, annual precipitation is reduced to levels similar to those recorded at the lowlands $(3,616 \mathrm{~mm})$ (Meave et al. 2006). Evaporation data are almost nonexistent; only for Vista Hermosa there is a record of $1,131 \mathrm{~mm}$, which implies that water availability for plants at this location is very high. During the relatively dry winter, La Chinantla still receives some rain during climatic events known as nortes, characterized by cool, moist winds. Moreover, fog condensation (a phenomenon also known as horizontal precipitation) contributes substantially to water entry into the system (Vogelmann 1973). For these reasons, La Chinantla is by far the rainiest region of Mexico and its climate may be classified as hyper-humid (Rowshan et al. 2007, Shen \& Chen 2010). Excess water is drained through multiple creeks and rivers, eventually forming the Papaloapan River that discharges into the Gulf of Mexico (Trejo 2004). Air temperature also shows an extraordinary variation in the region, mostly seen as a sharp decrease with increasing elevation; at the lowest elevations climate is hot (mean annual temperature $\left.>22{ }^{\circ} \mathrm{C}\right)$, but it changes to a semi-hot climate $\left(18-22{ }^{\circ} \mathrm{C}\right)$, temperate $\left(12-18{ }^{\circ} \mathrm{C}\right)$, and a cold one $\left(5-12^{\circ} \mathrm{C}\right)$ towards higher elevations (Meave et al. 2006).

The lush vegetation cover superimposed to this steep climatic gradient and intricate geomorphological mosaic is also highly complex (Rincón-Gutiérrez 2007). The native forests are more or less organized in parallel altitudinal belts, although this pattern is often broken by the presence of deep ravines, exposed ridges and different slope aspects. Broadly speaking, plant communities of La Chinantla may be classified as tropical rain, tropical evergreen and mesophyllous montane forests (Miranda \& Hernández-X. 1963, Rzedowski 1978), or as lowland, pre-montane, lower montane and upper montane forests, according to the forest classification developed for the ecologically similar montane forest cline of Costa Rica (Kappelle 1996). Despite a generally very good conservation status of these forests, human activities are leaving an important footprint in the area, particularly below the 1,000 m contour, where much of the land has been transformed into agricultural fields, mostly for the cultivation of maize. At higher elevations coffee plantations are also common, and these are typically shaded by native trees (Bandeira et al. 2005). At these lower elevations, secondary vegetation stands with different times since abandonment intermingle with patches of primary vegetation (van der Wal 1998, Romero-Romero et al. 2000).

Checklist preparation. In assembling the checklist of the vascular flora for La Chinantla, we integrated the findings of various more or less independent projects in which the authors of this contribution participated. The majority of the information derives from a floristic survey conducted in the higher portions of La Chinantla between 1993 and 1997. In total, we made 16 trips that summed 89 days of plant-specimens collecting in this area. Previously, we conducted an initial phase of plant collecting and vegetation sampling that encompassed seven field trips (19 days). Moreover, during one year (1995-1996) 18 stands of secondary vegetation ranging from 5 to 50 years old were sampled (six field trips with 66 days in the field). In total, we defined 93 geo-referenced localities (Figure 1). The total elevational range covered by the entire floristic survey was 250-3,040 m a.s.l., although the strongest effort concentrated above $800 \mathrm{~m}$.

Most specimens were collected in fairly pristine plant communities far away from roads and paths; while this made the botanical survey somewhat inefficient, it allowed us to include multiple species that are typical primary forest components. Being distant from laboratory facilities, we soaked the plant specimens in diluted alcohol to ensure its preservation (Calzada \& Perales-Rivera 1990). Plant determination was initially done by the authors, but the reliability of the taxonomic information depended mostly on the judgment of expert taxonomists in different plant groups (Table 1). When the specimen processing and species determination phases 
Table 1. Names of expert taxonomists that assisted in the identifications of plant specimens collected in La Chinantla region, Northern Oaxaca Range, Mexico. This list excludes some people who have provided/updated species names over two decades for specimens deposited at MO and MEXU.

Alfonso Delgado Salinas

Adolfo Espejo Serna

Abisaí García Mendoza

Ana Rosa López Ferrari

Angélica Ramírez Roa

Alan Reid Smith

Aarón Rodríguez Contreras

Charlotte M. Taylor

Douglas C. Daly

Eduardo A. Pérez García

María Esther León Velasco

Enrique Ortíz Bermúdez

Ernesto Velázquez Montes

Francisco G. Lorea Hernández

Gerardo A. Salazar Chávez

Gabriel Flores Franco

Hilda Belmont
Helga Ochoterena Booth

Isidro Méndez Larios

Isela Rodríguez Arévalo

Isolda Luna Vega

Jaime Alejandro Torres Montúfar

Jaime Jiménez Ramírez

José Luis Villaseñor Ríos

Jon Ricketson

John Thomas Mickel

Lourdes Rico Arce

Luz María González Villareal

Lucio Lozada Pérez

Marie-Stéphanie Samain

Miguel Ángel Soto Arenas ₹

Mónica Elías González

Mónica Palacios Ríos

Michael Nee
Mario Sousa Sánchez ₹

Nelly Diego Pérez

Oswaldo Téllez Valdez

Patricia Dávila Aranda

Peter Fritsch

Patricia Magaña Rueda

Rafael Fernández Nava

Rafael Lira Saade

Ricardo de Santiago Gómez

Rosa María Fonseca Juárez

Salvador Arias Montes

Susana Valencia Ávalos

Sergio Zamudio Ruíz

Thomas F. Daniel

Verónica Juárez Jaimes

Victor W. Steinmann

‡ Deceased.

were completed, specimens were deposited in several herbaria. The first and only complete set is deposited at MEXU (Instituto de Biología, UNAM, Mexico City), and further albeit incomplete sets were distributed in herbaria located in Mexico (XAL, OAX, CHAPA, IEB, SERO, ENCB, FCME) and abroad (MO, K). The taxonomic arrangement of the checklist follows APG III (Chase \& Reveal 2009, The Angiosperm Phylogeny Group 2009, Christenhusz et al. 2011a, b, Reveal \& Chase 2011, Stevens 2015). All names included in the checklist were verified in the Tropicos online database (www.tropicos.org) and The Plant List website (www.theplantlist.org). Information for some specimens deposited at MEXU could be updated through the UNIBIO database (unibio.unam.mx).

\section{Results}

We collected 2,653 specimens, each with at least three but generally with more than five duplicates. The checklist includes 1,021 species distributed in 471 genera and 162 families. Although the proportion of species that could be fully determined is high $(84.8 \%), 26$ species $(2.5 \%)$ could be only determined to family, and a further $130(12.7 \%)$ were determined to genus level (all these cases were tallied as morphospecies). These figures correspond to a genus/family ratio of 2.91 , a species/genus ratio of 2.03 , and a species/family ratio of 6.30 . The overall specimens/ species ratio (2.6) reflects a satisfactory collecting effort, although for some groups this effort was slightly lower (Lycopodiophyta, 1.82 specimens/species). More than half of all species are Eudicots; behind them, with considerably lower species richness, Monocots, Pteridophyta and Magnoliidae also emerged as important components of the La Chinantla flora (Table 2).

Table 2. Distribution of vascular plant species from the La Chinantla region (Oaxaca, Mexico) among major plant groups.

\begin{tabular}{lrrrrc} 
Plant group & Families & Genera & Species & Specimens & $\begin{array}{c}\text { Specimens/ } \\
\text { Species }\end{array}$ \\
\hline Lycopodiophyta & 2 & 3 & 11 & 20 & 1.82 \\
Pteridophyta & 20 & 53 & 120 & 246 & 2.05 \\
Gimnospermopsida & 4 & 5 & 9 & 27 & 3.00 \\
Magnoliidae & 8 & 21 & 105 & 304 & 2.90 \\
Eudicots & 108 & 317 & 608 & 1623 & 2.67 \\
Monocots & 20 & 72 & 168 & 433 & 2.58 \\
Total & 162 & 471 & 1021 & 2653 & 2.60 \\
\hline
\end{tabular}


Overall, families with the highest genus richness also have the largest species richness (Figure 2). In this regard, the three most remarkable families were Asteraceae (36 genera and 68 species), Rubiaceae $(18,60)$, and Orchidaceae $(28,59)$. In strong contrast to these highly diverse families, the checklist includes a considerable proportion of families $(51.6 \%)$ with low richness of lower taxa (53 families with a single genus and a single species, 17 families with one genus only and two species, and 14 families with two genera and two species). There were three exceptions to the increasing trend of species with the increasing number of genera, namely Aspleniaceae, Begoniaceae and Piperaceae; in these families the number of species greatly exceeds the number of genera that they should have according to the general trend.

Figure 2. Relationship between genus-level richness and species-level richness in the families included in the checklist of vascular plants for the La Chinantla region. The names of the families with the largest numbers of genera and species are shown (bold typeface indicates those families encompassing more than 10 genera or more than 10 species). The numbers adjacent to the dots specify how many families possess such combination of numbers of genera and species.

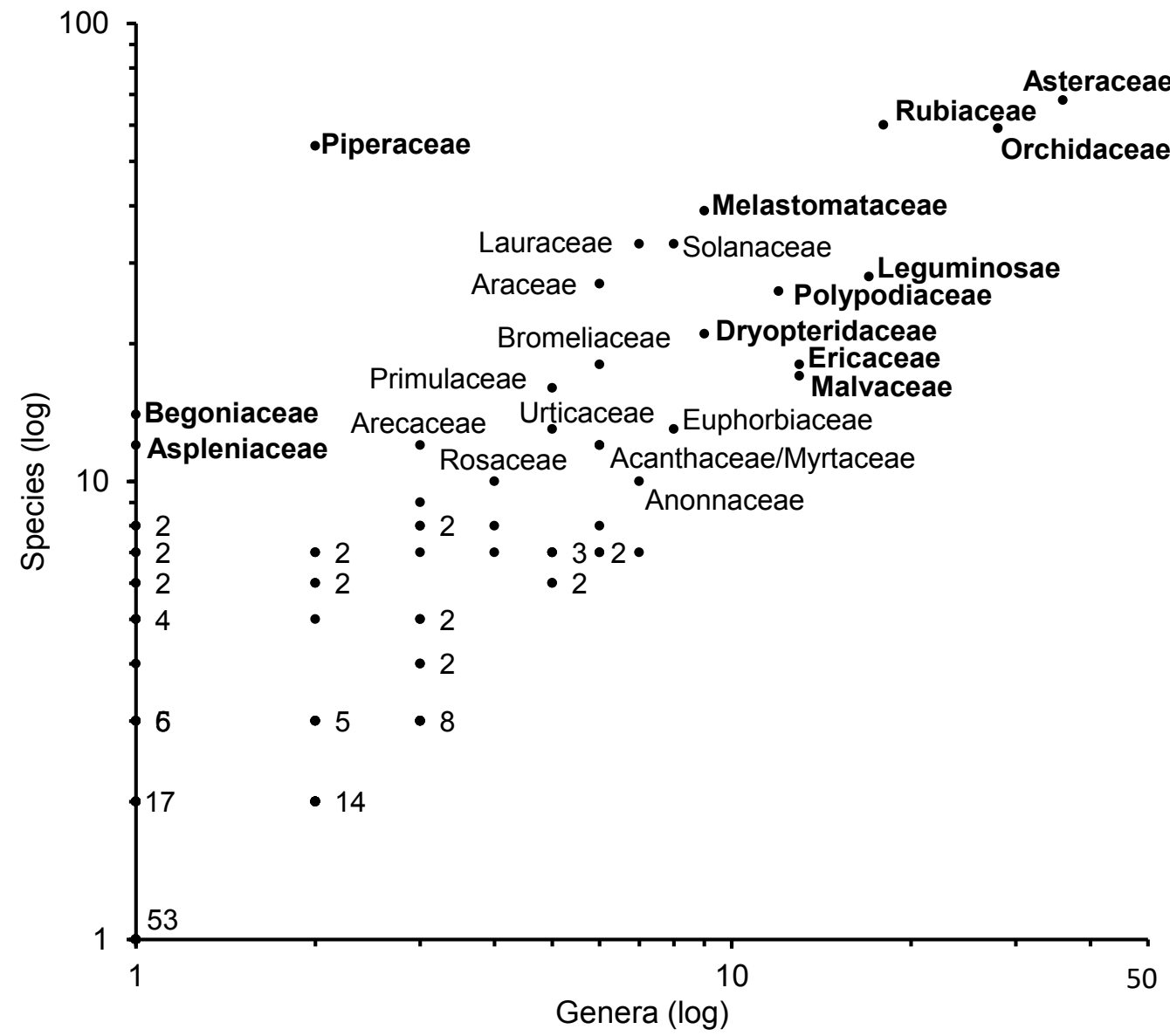

The uneven distribution of taxon diversity observed at the family level also characterized the genus level, as a few genera concentrated large numbers of species: Peperomia (29), Miconia and Piper (25 each), Begonia (14), Psychotria and Solanum (13 each), Anthurium, Asplenium and Ocotea (12 each), Lepanthes (11), and Arachnotryx, Chamaedorea and Tillandsia (10 each). In contrast, a total of 305 genera (29.8\%) are represented by one species only.

During the floristic survey we recorded the growth form and growth habit for each specimen. When this information was condensed by species, it became clear that some species could be placed in more than one class of each of these two classifications. Table 3 shows the distribution of species among categories. Regarding growth form, herbs and trees were the most numerous categories, with $484(47.3 \%)$ and $360(35.2 \%)$ species, respectively; at the other end cycads and tree ferns, two rare or absent growth forms in many floras, had two and ten species, respectively. Distribution of species in growth habit categories was also very heterogeneous; although terrestrial plants strongly prevailed (874 species, $85.4 \%$ ), the number of epiphytic species was also considerable (172 species, $15.9 \%)$.

The distribution of species along the elevational gradient was also quite heterogeneous. The numbers of species recorded were smaller for the locations corresponding to the lowest (low- 
Table 3. Distribution of species by growth form and growth habit categories. Percent values do not add to $100 \%$ for all growth habit categories because some species were placed in more than one class according to these criteria.

\begin{tabular}{lrc} 
Category & Species & Percent \\
\hline Growth form & & \\
Cycad & 2 & 0.20 \\
Tree fern & 10 & 0.98 \\
Palm & 12 & 1.17 \\
Liana & 47 & 4.59 \\
Herb \& Herb-shrub & 484 & 47.31 \\
Shrub & 108 & 10.56 \\
Shrub-tree \& Tree & 360 & 35.19 \\
Growth habit & & \\
Climber & 67 & 5.84 \\
Epiphyte \& Hemi-epiphyte & 172 & 15.00 \\
Rupicolous & 34 & 2.96 \\
Terrestrial & 874 & 76.20 \\
\hline
\end{tabular}

land, i.e., $<800 \mathrm{~m}$ ) and the highest (upper montane, i.e., $>2,300 \mathrm{~m}$ ) elevations, with 209 and 199 species, respectively. In contrast, the largest number of species (557) was recorded for the pre-montane forest belt $(800-1,400 \mathrm{~m})$, which was followed by the lower montane $(1,400-2,300 \mathrm{~m}$ belt; 383 species). It is necessary to clarify that this distribution does not reflect truthfully different levels of plant diversity at different elevations; although the lower richness recorded at the highest elevations may be relatively real, the small number of species from the lowlands is rather due to a considerably smaller collecting effort there (Figure 3). Despite this caveat, it is clear that pre-montane and lower-montane forests belts concentrate very high diversity levels. In addition, these belts also concentrate the largest numbers of exclusive species (349 and 187 species, respectively). As expected, there was a considerable degree of floristic

Figure 3. Numeric distribution of the species included in the checklist of the vascular plants for the La Chinantla region in four elevational zones. The size of the colored ovals is representative of the differential species richness recorded at each elevational zone. Figures in brackets indicate the total size of the flora recorded at each zone. The remaining numbers indicate either how many species are exclusive of each elevational zone (figures for the non-overlapping sections of the alveoli), or are shared between them, either in pairs, triads or the single possible tetrad.

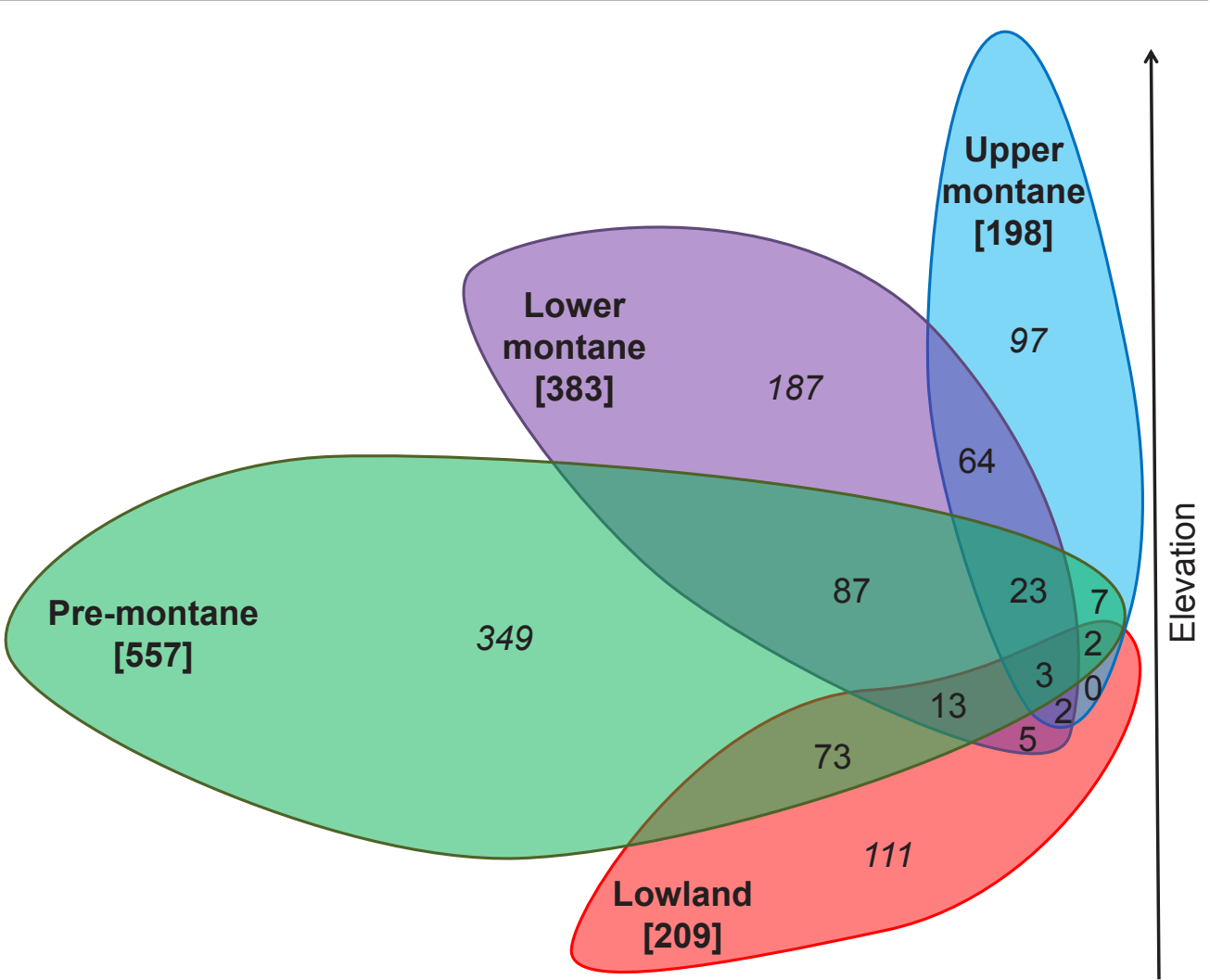


overlap between these belts, with the pre-montane and lower montane belts having the largest number of shared species (87), a figure closely followed by the intersection of the lowland-premontane intersection (73); the pre-montane, lower upper montane intersection included much fewer species (23). Only three species occurred across the four elevational belts, and no single species was shared between the lowland and the upper montane forest only (i.e., absent from the two intermediate belts).

\section{Discussion}

The floristic survey conducted in La Chinantla and the continued study of the plant collections made there demonstrate beyond any doubt that, with over 1,000 species of vascular plants, this region in northern Oaxaca hosts a very rich and one of the most unique floras in the Mexican territory. Admittedly, however, the floristic survey conducted by us in this topographically complex territory is by no means exhaustive. For example, after many frustrated attempts, we were unable to reach some areas where plant collecting had been originally scheduled based on cartographic analysis (e.g., areas particularly distant from roads and human settlements). Moreover, the collecting effort devoted to the lower elevations (i.e., the lowland forests) was very limited compared to that made at higher elevations. Such bias in this floristic inventory may explain, at least partially, why our observed species/genus (2.03) and species/family (6.35) ratios were lower than the national means (3.5 and 8.2, respectively) reported by Villaseñor (2016).

Even though the total size of the flora thriving in La Chinantla is still unknown, an educated guess of the real richness based on a few back-of-the-envelope calculations is possible. Most likely, the less accurate account reported by us is that for the lowland area (209 species). For the relatively close Los Tuxtlas region in Veracruz state, Ibarra-Manríquez \& Sinaca-Colín (1995, 1996a, b) reported around 940 species; thus, a conservative estimate of the real richness in the La Chinantla lowlands would be 700 species (rainfall at Los Tuxtlas is higher than at La Chinantla lowlands). Then, by making the also conservative assumption that for each of the higher elevational belts we missed around $10 \%$ of the plant species occurring there, we come up with the figure of 1,954 species (the sum of the so 'corrected' figures 700, 613, 422, and 219, to be compared with those in Figure 3). To this number we must subtract the potential floristic overlap (the numbers of observed shared species between belts increased each by $10 \%$ ). The result of these calculations is 1,647 species, a figure that is not unrealistic and that would be roughly equivalent to $c a .7 \%$ of the Mexican flora (Villaseñor 2016).

If such speculative exercise is worth anything, this would be to underline the need to make sustained efforts to continue studying the flora of this region in the future, as we found evidence that it contains very important components both for the flora of Oaxaca state and the entire country. For example, our checklist contains 60 species that are absent from the most updated and comprehensive catalogue of vascular plant species produced for the entire Oaxaca state (García-Mendoza \& Meave 2011), which resulted from the collaboration of dozens of experts in plant taxonomy and floristics; these species are indicated with an asterisk (*) in the Appendix. In addition, our checklist includes 75 species that did not make their way into the recently published checklist of vascular plants of Mexico (Villaseñor 2016), an unprecedented, colossal work based on many years of thorough and critical examination of virtually all floristic information available for the country, including sources of difficult access in gray literature. Also relevant is the fact that our floristic survey demonstrated the region's worth in terms of endemism, as it hosts 39 taxa endemic to Oaxaca (García-Mendoza \& Meave 2011), a figure that will likely increase in the future as our knowledge on this region's flora improves.

Despite these peculiarities of the La Chinantla floristic array, it is also noteworthy that it shares some attributes with the Mexican flora in general. This is exemplified by the prevalence in the La Chinantla flora of four of the six most speciose families in Mexico, namely Asteraceae, Leguminosae, Orchidaceae, and Rubiaceae (Villaseñor 2016). A detailed comparison with the floristic sets of other regions is a good way to uncover this flora's singularities; unfortunately, selecting regions to perform such comparison with the results of our study is not easy, given the large differences in the size of the area covered by the surveys and the amplitude of the elevational gradient comprised in the different studies. Bearing these considerations in mind, 
here we make two comparisons that are particularly revealing. First, we compared the flora of La Chinantla (ca. 459,000 ha; de Teresa 1999) with the Omiltemi region, Guerrero (approximate area of 3,600 ha, 1,800-2,800 m a.s.l.); there, Jiménez-Ramírez et al. (1993) recorded a lower richness (698 species) than that of La Chinantla, but in both regions Orchidaceae was a prevalent family (103 species in Omiltemi; Salazar-Chávez 1993), in addition to Asteraceae and Leguminosae. A second comparison was made with Cerro Quetzal, located in the El Triunfo Biosphere Reserve, Chiapas (11,988 ha; 1,200-2,300 m a.s.1.); this region and La Chinantla host similar plant communities, typical of very humid areas. For Cerro Quetzal, Pérez-Farrera et al. (2012) also reported a smaller richness of vascular plant species (795) than at La Chinantla; interestingly, however, this region bears a higher similarity with La Chinantla than with Omiltemi regarding not only the most speciose families (Asteraceae, Leguminosae, Orchidaceae, Rubiaceae, Dryopteridaceae, Melastomaceae, Piperaceae, and Polypodiaceae), but also the most speciose genera: Asplenium (Aspleniaceae), Begonia (Begoniaceae), Peperomia, Piper (both Piperaceae), and Psychotria (Rubiaceae). The prevalence of these groups may be an emergent pattern of Mesoamerican floras typical of hyper-humid regions.

In preparing the plant checklist for La Chinantla, we faced large difficulties for obtaining reliable determinations for our specimens. The ultimate implication was that this project required a much larger investment of time than anticipated. These obstacles were mostly due to the still incipient knowledge of the flora of this hyper-humid region, as it encompasses numerous taxa with imprecise systematic delimitation. Thorough monographic works for these taxa are lacking or are being currently prepared at best. Some species-rich families and genera of this flora, such as Asteraceae, Myrtaceae, Melastomataceae, and Begonia, Peperomia, and Piper, provide examples of this situation. However, not only speciose families and genera posed difficulties; actually, the numerous families (53) represented by a single genus each (often by a single species) in the region represented another problematic group. As a rule, we were unable to locate expert taxonomists specialized in these families, perhaps because few botanists are attracted to them due to their low diversity. Therefore, determination of these specimens was very time consuming. Once the familiar adscription of such taxa gets solved, it is usually easier to find out the generic and specific identities. Given the considerable contribution of these species to the total flora, their inclusion in regional floras or field guides should be of high priority. In fact, this situation is not unique to the La Chinantla flora, as the Mexican flora comprises 44 families that are each represented by a single species (Villaseñor 2016). Examples of these taxa occur in all major groups like ferns (Plagiogyraceae), gymnosperms (Taxaceae), and angiosperms (Altingiaceae, Chloranthaceae or Winteraceae). Interestingly, many such families are typical representatives of forests occurring in very humid mountains (Rzedowski 1996).

For all these reasons, many years went by before we achieved an acceptable level of taxonomic resolution for our plant collection. Even so, we were unable to provide full determinations for many taxa and these remained catalogued as morphospecies. For some of them it was possible to assign their generic adscription but for others we went as far as family level only (for a few specimens not even the family could be recognized, and these were excluded from the checklist). Actually, we suspect that many - if not most - of these morphospecies will turn out to be new taxa for science. There are several reasons pointing to this possibility. Among Lauraceae, Ocotea sauroderma Lorea-Hern. and Licaria chinanteca Lorea-Hern. were described based on material collected during this project (Lorea-Hernández 1999, 2001); they represent two cases of species recognized as new taxa as soon as they were examined by an expert taxonomist in the family. Similarly, continuous visits to the internet-hosted databases of the Missouri Botanical Garden (www.tropicos.org) and the National Herbarium of Mexico (unibio.unam. $\mathrm{mx}$ ) resulted in a ceaseless stream of species determinations thanks to the work of numerous taxonomists visiting these herbaria over the last two decades. In some cases, this work revealed that other specimens also represent undescribed species (e.g., Anthurium sp. nov., Araceae, A. Rincón 373). Curiously, the expert taxonomist of this family, Thomas B. Croat, determined the new species status for this collection based on a duplicate specimen deposited at XAL, while such recognition was not available for the specimens deposited in the larger - and more frequently visited - herbaria MEXU and MO. These cases confirm Villaseñor's (2015) tenet that La Chinantla should be regarded as an area with high speciation rates (based on the analysis of 
the species/families and species/genera ratios); on this ground that author highlighted this as a high priority region for the search of new taxa for science. In this regard, plant groups such as Anthurium, Arachnotryx, Asplenium, Begonia, Chamaedorea, Lepanthes, Miconia, Ocotea, Peperomia, Piper, Psychotria, Solanum, and Tillandsia are very promising and deserve particular attention.

An additional consideration about the group of morphospecies is that they do not represent just one or few plant types, as they included plants representing a range of growth forms and habits (Appendix); by growth form variously-sized trees are noteworthy (49 species), as well as many terrestrial and epiphytic herbs (32 and 22 species, respectively), and shrubs (23). The group of morphospecies also comprised a broad range of families (58), for some of which expert taxonomists are available (e.g., Bromeliaceae, Cyatheaceae, Fagaceae, Selaginellaceae, and Solanaceae). This situation pinpoints once more the necessity to carefully examine these specimens by the specialists. However, it is also likely that at least in some cases they could not be properly determined due to the lack of diagnostic structures, as they did not always bear flowers or fruits. Alternatively, they may represent highly variable groups for which more collections are needed in order to critically assess their morphological differentiation from accepted known species. Whatever the case may be, these problems will only be solved with better and longer botanical surveys in La Chinantla; to this end, one plausible strategy is the training of professional parataxonomists living in the region, as this would very likely increase the efficacy of collecting plant specimens.

Another interesting attribute of our checklist is that many species included in it represent groups (of any taxonomic level) that are poorly represented at herbaria. In fact, our specimens still are the only representatives of several species either at MO or MEXU. This situation may be reflecting a high degree of endemism, but it could also result from the widespread strategy that characterizes most botanical surveys that consists in conducting plant surveys in readily accessible localities, or in zones with adequate infrastructure, such as some formally decreed natural protected areas. If we are ever going to get a more complete knowledge of the Mexican flora, this approach must be revised.

Regardless of these possibilities, it appears that rarity is a common phenomenon among the plant species of La Chinantla. Rabinowitz (1981) distinguished three components of rarity (population density, geographical range and ecological breadth). Plant species may be rare according to low values of any one of these three criteria, or to combinations of them (only high values for the three criteria do not result in rarity). Although we lack precise information to formally analyze the prevalence of rarity in the La Chinantla flora, there are indications (number of specimens in the herbaria, number of specimens collected by us, elevational spread of the species) to substantiate the hypothesis that a considerable proportion of these species possess some degree of rarity. The Red List of Mexican Cloud Forest Trees (González-Espinosa et al. 2011), allowed us to evaluate this attribute for some species included in the present study, because IUCN Red List categories are indicative of the degree to which their conservation is threatened. There are 123 species in the following categories: 10 Critically Endangered, 42 Endangered, 45 Vulnerable, and 26 Near Threatened. In contrast, only 70 were assigned to the Least Concern category. Further evidence is provided by the study of the genus Peperomia in Veracruz state (Vergara-Rodríguez et al. 2017); there are 13 species shared between this state and La Chinantla, 11 of which were listed as Least Concern, whereas P. petrophila C.DC. was classified as Vulnerable and P. peltilimba C.DC. ex Trel. as Near Threatened. A final consideration on these two latter species and for five of those listed as LC is that they are epiphytes, which actually increases their conservation risk due to habitat loss, as they fully depend on their host plants for their establishment.

Information on species' elevational ranges is useful in making an initial assessment of their ecological breadth. By dividing the area covered by our floristic survey in four elevational belts corresponding to distinctly different forest types (lowland, pre-montane, lower montane and upper montane), we could assess the proportions of species exclusive of each belt $v s$. species with broad elevational distribution (Figure 3). Only three species, namely one fern (Polypodium plebeium), and two woody vascular plants (Dendropanax arboreus and Hoffmania nicotianifolia) were collected in all four elevational zones. This is not surprising, as strong floristic gradients have been reported along the slopes of the mountains of southern and western Mexico 
(Vázquez-G. \& Givnish 1998, Salas-Morales \& Meave 2012). In fact, the reality may be even more complex; for example, Dendropanax arboreus exhibits strong morphological differentiation along the elevational gradient, growing as a tall, rather sturdy tree in the lowlands, and as a slim, short-statured shrub in the upper reaches, casting doubts on the recognition of these contrasting morphologies as a single species. More importantly, however, is the fact that for the total set of species collected at each elevational zone, the numbers of exclusive species are always larger (sometimes much more so) than the numbers of shared species between adjacent zones, whereas the numbers of species shared by three zones (2-23) are very low. Species common to non-adjacent elevational zones are even fewer. In addition, detailed analyses conducted for two plant groups (Quercus, Meave et al. 2006; Lauraceae, Rincón-Gutiérrez 2007) revealed narrow elevational ranges for all examined species. It would be worth to analyze with greater detail the specific shape of the floristic turnover along the entire gradient in the future, in order to identify those elevations at which the largest floristic changes take place.

An important shortcoming of this study is the uneven collecting effort along the elevation gradient. Despite this limitation, the reduction in floristic richness with increasing elevation is clear, particularly in those areas located above 2,300 m (upper montane), in strong contrast with the richness recorded for the pre-montane forest belt (800-1,400 m; 557 species), as well as in the lower montane forest (1,400-2,300 m belt; 383 species). The insufficient floristic knowledge for lower elevations prevents us from drawing more definite conclusions about the general floristic pattern at La Chinantla. Currently, two main patterns have been observed, namely a humpshaped pattern with the largest richness at intermediate elevations, and a continuous decreasing pattern (Bhattarai \& Vetaas 2003, Gould et al. 2006, Grytnes \& Beaman 2006, Kluge \& Kessler 2011, Salas-Morales \& Meave 2012). At present, it is uncertain which of them will better match the floristic gradient at La Chinantla.

Our study confirms the large contribution of the Northern Oaxaca range to Mexico's biological heritage. Except for those plant communities proper of lower elevations $(<1,000 \mathrm{~m})$, many of which have been cleared to give way to productive systems, the various plant communities occurring in the region still have a good conservation status. This is noteworthy not only because of the area they occupy, but also because of their peculiar floristic composition and physiognomy. For example, the presence of very rare taxa such as Cyrilla, Juglans, Oreomunnea, Podocarpus, and Ticodendron (Martin \& Madrid 1992, Meave et al. 1996, Gallardo et al. 1998), as well as the notoriously large richness of Lauraceae species, suggests that this is a very unique flora due to these antique and rare lineages (Rzedowski \& Palacios-Chávez 1977), uncommon elsewhere in Mexico. Moreover, some plant communities of the region possess particular physiognomies, often characterized by very tall trees with large trunks, by the twisted appearance of trees in some upper montane forests, and frequently by the abundance of epiphytic plants, even at low heights on tree trunks, including numerous species of bromeliads, ferns, orchids and Peperomia. Last, but no least, the considerable area and continuity of these forests results in eye-catching landscapes rarely seen in other regions of the country.

Notwithstanding this comparatively favorable situation, and like many other forested regions of the planet, particularly in tropical mountains, the vulnerability of La Chinantla's forest ecosystems needs recognition, as shown by relatively small actions that have strongly impacted the vegetation. One such action was the construction of the road connecting the isolated village of Santa Cruz Tepetotutla, located in the core of our study area. After several failed attempts to build this road through different routes, the final stroke obliterated a beautiful and well-preserved piece of elfin forest where many of our collections came from. Fortunately, the situation does not seem to be so serious and in fact it is promising, as in this region several communitybased conservation initiatives and programs of payment for ecosystem services exist (Martin et al. 2011, Bray et al. 2012, Velasco-Murguía et al. 2014). Yet, the diversification of sources of income through activities that better match conservation goals, such as eco-tourism, fish production in ponds, or even biodiversity-friendly coffee plantations (Bandeira et al. 2005), would be desirable. These efforts require the largest possible support from societies in Mexico and abroad in order to guarantee the long-term protection of these unique forests and the biota they host. We hope that the floristic information produced in this study will contribute to the fulfillment of this important objective. 


\section{Acknowledgments}

We are grateful to the Chinantec people and their authorities, who granted permission to conduct the floristic survey on their lands, and who offered continuous assistance in many ways. We are particularly indebted to Mr. Pedro Osorio, who accompanied us on many expeditions and himself collected numerous plant specimens around his home village. We owe a debt of gratitude to the many specialists of different plant groups, who shared their knowledge in determining or confirming plant identifications. Many thanks to everyone who participated in the botanical surveys; their friendly support enriched the field work in all aspects. This study received financial support from the Mexican National Commission of Biodiversity (CONABIO grant FB063/ P069/93), and the Program for the Integrated Use of Natural Resources (PAIR) from Facultad de Ciencias, Universidad Nacional Autónoma de México.

\section{Literature cited}

Alfaro GS. 2004. Suelos. In: García-Mendoza AJ, Ordóñez MJ, Briones-Salas M, eds. Biodiversidad de Oaxaca. Mexico City: Universidad Nacional Autónoma de México, Fondo Oaxaqueño para la Conservación de la Naturaleza and WWF, 55-65.

Álvarez-Arteaga G, García-Calderón NE, Krasilnikov PV, Sedov SN, Targulian VO, Velázquez-Rosas N. 2008. Soil altitudinal sequence on base-poor parent material in a montane cloud forest in Sierra Juárez, Southern Mexico. Geoderma 144: 593-612. DOI: 10.1016/j.geoderma.2008.01.025

Arellanes-Cancino Y. 2000. Análisis estructural de un bosque mesófilo de montaña de Ticodendron incognitum en la Sierra Norte de Oaxaca, México. B.Sc. Thesis, Universidad Nacional Autónoma de México.

Bandeira FP, Martorell C, Meave JA, Caballero J. 2005. The role of rustic coffee plantations in the conservation of wild tree diversity in the Chinantec region of Mexico. Biodiversity \& Conservation 14: 1225-1240. DOI: 10.1007/s10531-004-7843-2

Bhattarai KR, Vetaas OR. 2003. Variation in plant species richness of different life forms along a subtropical elevation gradient in the Himalayas, east Nepal. Global Ecology \& Biogeography 12: 327-340. DOI: 10.1046/j.1466-822X.2003.00044.X

Boyle BL. 1996. Changes on altitudinal and latitudinal gradients in Neotropical montane forests. Ph.D. Dissertation, Washington University.

Bray DB, Durán E, Molina O. 2012. Beyond harvests in the commons: multi-scale governance and turbulence in indigenous/community conserved areas in Oaxaca, Mexico. International Journal of the Commons 6: 151-178. DOI: $10.18352 / \mathrm{ijc} .328$

Calzada JI, Perales-Rivera H. 1990. La preservación con alcohol de ejemplares colectados para herbario. Boletín de la Sociedad Botánica de México 50: 151-155. DOI: 10.17129/botsci.1382

Centeno-García E. 2004. Configuración geológica del estado. In: García-Mendoza AJ, Ordóñez MJ, Briones-Salas M, eds. Biodiversidad de Oaxaca. Mexico City: Universidad Nacional Autónoma de México, Fondo Oaxaqueño para la Conservación de la Naturaleza and WWF, 29-42.

Chase MW, Reveal JL. 2009. A phylogenetic classification of the land plants to accompany APG III. Botanical Journal of the Linnean Society 161: 122-127. DOI: 10.1111/j.1095-8339.2009.01002.x

Christenhusz MJM, Reveal JL, Farjon A, Gardner MF, Mill RR, Chase MW. 2011a. A new classification and linear sequence of extant gymnosperms. Phytotaxa 19: 55-70. DOI: 10.11646/phytotaxa.19.1.3

Christenhusz MJM, Zhang XC, Schneider H. 2011b. A linear sequence of extant families and genera of lycophytes and ferns. Phytotaxa 19: 7-54. DOI: 10.11646/phytotaxa.19.1.2

De Teresa AP. 1999. Población y recursos en la región chinanteca de Oaxaca. Desacatos, Revista de Antropología Social 1: 125-151.

Ferrusquía-Villafranca I. 1993. Geology of Mexico: a synopsis. In: Ramamoorthy TP, Bye R, Lot A, Fa J, eds. Biological Diversity of Mexico: Origins and Distribution. New York: Oxford University Press, 3-107.

Gallardo C, Meave J, Rincón A. 1998. Plantas leñosas raras de bosque mesófilo de montaña IV. Cyrilla racemiflora L. (Cyrillaceae). Boletín de la Sociedad Botánica de México 62: 183-186. DOI: 10.17129/ botsci. 1560

García-Mendoza AJ. 2004. Integración del conocimiento florístico del estado. In: García-Mendoza AJ, Ordóñez MJ, Briones-Salas M, eds. Biodiversidad de Oaxaca. Mexico City: Universidad Nacional Autónoma de México, Fondo Oaxaqueño para la Conservación de la Naturaleza and WWF, 305-325.

García-Mendoza AJ, Meave JA, eds. 2011. Diversidad Florística de Oaxaca: de Musgos a Angiospermas (Colecciones y Lista de Especies). Mexico City: Universidad Nacional Autónoma de México and CONABIO. 
Gómez-Pompa A, Hernández-Pallares L, Sousa-Sánchez M. 1964. Estudio fitoecológico de la cuenca intermedia del río Papaloapan. Instituto Nacional de Investigaciones Forestales, Publicación Especial 3: 37-90.

González-Espinosa M, Meave JA, Lorea-Hernández FG, Ibarra-Manríquez G, Newton AC. 2011 The Red List of Mexican Cloud Forest Trees. Fauna and Flora International.

González-Espinosa M, Ramírez-Marcial N, Méndez-Dewar G, Galindo-Jaimes L, Golicher D. 2005. Riqueza de especies de árboles en Chiapas: variación espacial y dimensiones ambientales asociadas e nivel regional. In: González-Espinosa M, Ramírez-Marcial N, Ruiz-Montoya L, eds. Diversidad Biológica en Chiapas. Mexico City: Plaza y Valdés, 81-125.

Gould WA, González G, Carrero-Rivera G. 2006. Structure and composition of vegetation along an elevational gradient in Puerto Rico. Journal of Vegetation Science 17: 653-664. DOI: 10.1111/j.16541103.2006.tb02489.x

Grytnes JA, Beaman JH. 2006. Elevational species richness patterns for vascular plants on Mount Kinabalu, Borneo. Journal of Biogeography 33: 1838-1849. DOI: 10.1111/j.1365-2699.2006.01554.x

Ibarra-Manríquez G, Mendoza A. 2003. Reinhardtia elegans Mart. (Arecaceae): una palma endémica del bosque mesófilo de montaña mexicano. Acta Botanica Mexicana 63: 47-54. DOI: 10.21829/ abm63.2003.917

Ibarra-Manríquez G, Sinaca-Colín S. 1995. Lista florística comentada de la Estación de Biología Tropical Los Tuxtlas, Veracruz, México. Revista de Biología Tropical 43: 75-115.

Ibarra-Manríquez G, Sinaca-Colín S. 1996a. Estación de Biología Tropical” Los Tuxtlas", Veracruz, México: lista florística comentada (Mimosaceae a Verbenaceae). Revista de Biología Tropical 44: 41-60.

Ibarra-Manríquez G, Sinaca-Colín S. 1996b. Lista comentada de plantas de la Estación de Biología Tropical" Los Tuxtlas", Veracruz, México: (Violaceaea-Zingiberaceae). Revista de Biología Tropical 44: 427-447.

INEGI. 2017. Mapa Digital Ver. 6.3.0, rev. 3520. Aguascalientes: Instituto Nacional de Estadística y Geografía. <www.inegi.org.mx/geo/contenidos/mapadigital/>. Accessed on July 24, 2017.

Jiménez-Ramírez J, Contreras-Jiménez JL, González-Flores RE, Antonio-Ocampo R, Lozano-Valdés G, Torres-Reynoso S. 1993. Plantas Vasculares. In: Luna-Vega I, Llorente-Bousquets J. (eds.). Historia Natural del Parque Ecológico Estatal Omiltemi, Chilpancingo, Guerrero, México. Mexico City: Universidad Nacional Autónoma de México, 127-250.

Kappelle M. 1996. Los Bosques de Roble (Quercus) de la Cordillera de Talamanca, Costa Rica: Biodiversidad, Ecología, Conservación y Desarrollo. San José: Instituto Nacional de Biodiversidad and Universiteit van Amsterdam, 319.

Kluge J, Kessler M. 2011. Influence of niche characteristics and forest type on fern species richness, abundance and plant size along an elevational gradient in Costa Rica. Plant Ecology 212: 1109-1121. DOI: 10.1007/s 11258-010-9891-x

Krömer T, Acebey A, Gómez-Pompa A. 2010. Introducción. In: Gómez-Pompa A, Krömer T, Castro-Cortés R, eds. Atlas de la Flora de Veracruz: un Patrimonio Natural en Peligro. Mexico City: Gobierno del Estado de Veracruz and Universidad Veracruzana, 25-42.

Lorea-Hernández FG. 1999. Una nueva especie de Licaria (Lauraceae) del sur de México. Polibotánica 10: $105-110$.

Lorea-Hernández FG. 2001. Dos especies nuevas de Ocotea (Lauraceae) del sur de México. Novon 11: 183-188. DOI: $10.2307 / 3393055$

Lorence DH, García-Mendoza A. 1989. Oaxaca, Mexico. In: Cambell DG, Hammond HD, eds. Floristic Inventory of Tropical Countries: The Status of Plant Systematics, Collections, and Vegetation, plus Recommendations for the Future. New York: New York Botanical Garden, 253-269.

Lorence DH, Torres-Colín R. 1988. Carica cnidoscoloides (sp. nov.) and sect. Holostigma (sect. nov.) of Caricaceae from Southern Mexico. Systematic Botany 13: 107-110. DOI: 10.2307/2419246

Martin GJ, Camacho-Benavides CI, Del Campo-García CA,Anta-Fonseca S, Chapela-Mendoza F, GonzálezOrtíz MA. 2011. Indigenous and community conserved areas in Oaxaca, Mexico. Management of Environmental Quality: An International Journal 22: 250-266. DOI: 10.1108/14777831111113419

Martin GJ, Madrid S. 1992. Ethnobotany, distribution, and conservation status of Ticodendron incognitum in northern Oaxaca, Mexico. Journal of Ethnobiology 12: 227-231.

Matuda E. 1959. Nuevas especies Anthurium de Oaxaca. Boletín de la Sociedad Botánica de México 24: 35-38. DOI: 10.17129/botsci.1059

Meave J, Gallardo C, Rincón A. 1996. Plantas leñosas raras del bosque mesófilo de montaña. II. Ticodendron incognitum Gómez-Laurito \& Gómez P. (Ticodendraceae). Boletín de la Sociedad Botánica de México 59: 149-152. DOI: 10.17129/botsci.1513

Meave JA, Rincón A, Romero-Romero MA. 2006. Oak forests of the hyper-humid region of La Chinantla, Northern Oaxaca Range, Mexico. In: Kappelle M, ed. Ecology and Conservation of Neotropical Montane Oak Forests. Berlin: Springer, 113-125. 
Miranda F, Hernández-X E. 1963. Los tipos de vegetación de México y su clasificación. Boletín de la Sociedad Botánica de México 28: 29-179. DOI: 10.17129/botsci.1084

Nixon KC. 1993. The genus Quercus in Mexico. In: Ramamoorthy TP, Bye R, Lot A, Fa J, eds. Biological Diversity of Mexico: Origins and Distribution. New York: Oxford University Press, 447-458.

Ortiz-Pérez MA, Hernández-Santana JR, Figueroa Mah-Eng JM. 2004. Reconocimiento fisiográfico y geomorfológico. In: García-Mendoza AJ, Ordóñez MJ, Briones-Salas M, eds. Biodiversidad de Oaxaca. Mexico City: Universidad Nacional Autónoma de México, Fondo Oaxaqueño para la Conservación de la Naturaleza and WWF, 43-54.

Paray L. 1951. Exploraciones en la Sierra de Juárez. Boletín de la Sociedad Botánica de México 13: 4-10. DOI: $10.17129 /$ botsci.973

Pérez-Farrera MÁ, Martínez-Camilo R, Martínez-Meléndez N, Farrera-Sarmento O, Maza-Villalobos S. 2012. Listado florístico del Cerro Quetzal (Polígono III) de la Reserva de la Biosfera El Triunfo, Chiapas, México. Botanical Sciences 90: 113-142. DOI: 10.17129/botsci.479

Perry JP. 1991. The Pines of Mexico and Central America. Portland: Timber Press.

Rabinowitz D. 1981. Seven forms of rarity. In: Synge H. (ed) The Biological Aspects of Rare Plant Conservation. Somerset: Wiley, 205-217.

Reko BP. 1949. Nombres botánicos chinantecos. Boletín de la Sociedad Botánica de México 8: 9-20. DOI: 10.17129/botsci.951

Reveal JL, Chase MW. 2011. APG III: Bibliographical Information and Synonymy of Magnoliidae. Phytotaxa 19: 71-134. DOI: 10.11646/phytotaxa.19.1.4

Rincón-Gutiérrez A. 2007. Estructura y composición florística de los bosque húmedos de montaña de Santa Cruz Tepetotutla, Oaxaca, México. B.Sc. Thesis, Universidad Nacional Autónoma de México.

Romero-Romero MA, Castillo S, Meave J, van der Wal H. 2000. Análisis florístico de la vegetación secundaria derivada de la selva húmeda de montaña de Santa Cruz Tepetotutla (Oaxaca), México. Boletín de la Sociedad Botánica de México 67: 89-106. DOI: 10.17129/botsci.1627

Rowshan GR, Mohammadi H, Nasrabadi T, Hoveidi H, Baghvand A. 2007. The role of climate study in analyzing flood forming potential of water basins. International Journal of Environmental Research $\mathbf{1}$ : 231-236.

Rzedowski J. 1978. Vegetación de México. Mexico City: Limusa.

Rzedowski J. 1991. Diversidad y orígenes de la flora fanerogámica de México. Acta Botanica Mexicana 14: 3-21. DOI: 10.21829/abm14.1991.611

Rzedowski J. 1996. Análisis preliminar de la flora vascular de los bosques mesófilos de montaña de México. Acta Botanica Mexicana 35: 25-44. DOI: 10.21829/abm35.1996.955

Rzedowski J, Palacios-Chávez R. 1977. El bosque de Engelhardtia (Oreomunnea) mexicana en la región de la Chinantla (Oaxaca, México): una reliquia del Cenozoico. Boletín de la Sociedad Botánica de México 36: 93-127. DOI: 10.17129/botsci.1161

Salas-Morales SH, Meave JA. 2012. Elevational patterns in the vascular flora of a highly diverse region in southern Mexico. Plant Ecology, 213: 1209-1220. DOI: 10.1007/s11258-012-0077-6

Salazar-Chávez G. 1993. Orquídeas. In Luna-Vega I, Llorente-Bousquets J. (eds.). Historia Natural del Parque Ecológico Estatal Omiltemi, Chilpancingo, Guerrero, México. Mexico City: Universidad Nacional Autónoma de México, 251-285.

Sarukhán-Kermez J. 1968. Análisis sinecológico de las selvas de Terminalia amazonia en la planicie costera del Golfo de México. M.Sc. Thesis, Escuela Nacional de Agricultura.

Shen Y, Chen Y. 2010. Global perspective on hydrology, water balance, and water resources management in arid basins. Hydrological Processes 24: 129-135. DOI: 10.1002/hyp.7428

Sousa-Sánchez M. 1964. Estudio de la vegetación secundaria en la región de Tuxtepec, Oax. Instituto Nacional de Investigaciones Forestales, Publicaciones Especiales 3: 91-105.

Stevens PF. 2015. Angiosperm Phylogeny Website, APG III. University of Missouri, St Louis, and Missouri Botanical Garden, ver. 14. <www.mobot.org/MOBOT/research/APweb/> . Last accessed on May 26, 2017.

Tamayo JL, Beltrán E, eds. 1977. Recursos Naturales de la Cuenca del Papaloapan. Mexico City: SARH, Instituto Mexicano de Recursos Naturales.

The Angiosperm Phylogeny Group. 2009. An update of the Angiosperm Phylogeny Group classification for the orders and families of flowering plants: APG III. Botanical Journal of Linnean Society 161: 105121. DOI: DOI: 10.1111/j.1095-8339.2009.00996.x

Torres-Colín R, Lorence DH, Ramírez-de-Anda MP, Villa-Arce RE. 2009. Listados Florísticos de México. XXV. Flora de la Sierra de Juárez, Oaxaca: Distrito de Ixtlán y Áreas Adyacentes (Sierra Norte de Oaxaca). Mexico City: Instituto de Biología, Universidad Nacional Autónoma de México.

Trejo I. 2004. Clima. In: García-Mendoza AJ, Ordóñez MJ, Briones-Salas M, eds. Biodiversidad de Oaxaca. Mexico City: Universidad Nacional Autónoma de México, Fondo Oaxaqueño para la Conservación de la Naturaleza and WWF, 67-85. 
Valencia-Ávalos S, Nixon KC. 2004. Encinos. In: García-Mendoza AJ, Ordóñez MJ, Briones-Salas M, eds. Biodiversidad de Oaxaca. Mexico City: Universidad Nacional Autónoma de México, Fondo Oaxaqueño para la Conservación de la Naturaleza and WWF, 219-225.

van der Wal H. 1996. Modificación de la vegetación y el suelo por los chinantecos de Santiago Tlatepusco, Oaxaca, México. Etnoecológica 3: 37-58.

van der Wal H. 1998. Chinantec Shifting Cultivation and Secondary Vegetation: a Case-Study on Secondary Vegetation Resulting from Indigenous Shifting Cultivation in the Chinantla, Mexico. Wageningen: BOS Foundation.

Vázquez-G JA, Givnish TJ. 1998. Altitudinal gradients in tropical forest composition, structure and diversity in the Sierra de Manantlán. Journal of Ecology 86: 999-1020. DOI: 10.1046/j.1365-2745.1998.00325.x

Velasco-Murguía A, Durán-Medina E, Rivera R, Bray DB. 2014. Cambios en la cobertura arbolada de comunidades indígenas con y sin iniciativas de conservación, en Oaxaca, México. Investigaciones Geográficas, Boletín del Instituto de Geografía 83: 55-73. DOI: 10.14350/rig.34975

Vergara-Rodríguez D, Mathieu G, Samain MS, Armenta-Montero S, Krömer T. 2017. Diversity, distribution, and conservation status of Peperomia (Piperaceae) in the state of Veracruz, Mexico. Tropical Conservation Science 10: 1-28. DOI: 10.1177/1940082917702383

Villaseñor JL. 2015. ¿La crisis de la biodiversidad es la crisis de la taxonomía? Botanical Sciences 93: 1-12. DOI: $10.17129 /$ botsci.456

Villaseñor JL. 2016. Checklist of the native vascular plants of Mexico. Revista Mexicana de Biodiversidad 87: 559-902. DOI: 10.1016/j.rmb.2016.06.017

Villaseñor JL, Ibarra G, Ocaña D. 1998. Strategies for the conservation of Asteraceae in Mexico. Conservation Biology 12: 1066-1075. DOI: 10.1046/j.1523-1739.1998.97171.x

Vogelmann HW. 1973. Fog precipitation in the cloud forests of eastern Mexico. BioScience 23: 96-100. DOI: $10.2307 / 1296569$ 
Appendix. Floristic Checklist of La Chinantla, Oaxaca, Mexico.

Growth form: $\mathrm{T}=$ Tree, $\mathrm{S}=$ Shrubs, $\mathrm{L}=$ Liana, $\mathrm{H}=$ Herb, $\mathrm{TF}=$ Tree fern, $\mathrm{P}=$ Palm, CY = Cycade; Growth habit: ep = epiphyte, he = hemi-epiphyte, $\mathrm{ru}=$ rupicolous, te $=$ terrestrial, $\mathrm{cl}=$ climber. $\mathrm{LL}=$ Lowland, $\mathrm{PM}=$ Pre-montane, $\mathrm{LM}=$ Lower montane, $\mathrm{UM}=$ Upper montane. Collectors: $\mathrm{A}=$ Armando Rincón, C = Claudia Gallardo, E = Eduardo A. Pérez, G = Guillermo Ibarra, J = Jorge A. Meave, $M=$ Marco A. Romero, $\mathrm{P}=$ Pedro Osorio. * = species that are absent from the catalogue of García-Mendoza \& Meave (2011). Numbers in parentheses are genera and species per family.

\section{Lycophytes \\ LYCOPODIIDAE}

LYCOPODIACEAE (2/6)

Huperzia pithyoides (Schltdl. \& Cham.) Holub; H ep; LM; G 3905.

H. pringlei (Underw. \& F.E.Lloyd) Holub; H ep te; UM; C 1327, P 80 bis, 81 bis.

H. reflexa (Lam.) Trevis.; H te; UM; C 1786.

H. taxifolia (Sw.) Trevis.; H ep; LM; P 51.

Lycopodium clavatum L.; H te; UM; C 863, 1265.

L. thyoides Humb. \& Bonpl. ex Willd.; H te; LM, UM; C 873, 1947 bis.

SELAGINELLACEAE (1/5)

Selaginella flexuosa Spring; H te; LL, LM; J 1623, M 1030.

S. martensii Spring; H te; LL, M 447, 2153.

S. oaxacana Spring; $\mathrm{H}$ cl te; PM; C 1774, J 1643, P 116.

S. stellata Spring; H te; LL; M 739, 1260.

Selaginella sp.; $\mathrm{H}$ te; PM; C 1363.

\section{Ferns}

\section{MARATIIDAE}

MARATTIACEAE (2/2)

Danaea cuspidata Liebm.; H te; PM; M 1533.

Marattia weinmanniifolia Liebm.; H te; PM, LM, UM; C 1197, J 1729, M 1925.

POLYPODIIDAE

\section{ANEMIACEAE (1/1)}

Anemia phyllitidis(L.) Sw.; H te; PM; P 255.

ASPLENIACEAE (1/12)

Asplenium achilleifolium (M.Martens \& Galeotti) Liebm.; H te; PM; A 740, J 1965.

A. barbaense Hieron.; H ep te; LM; A 451, C 1205.

A. blepharophorum Bertol.; H te; UM; C 1128.

A. cirrhatum Rich. ex Willd.; H ep; PM, LM; C 1322, P 148 bis.

A. flabellulatum Kunze; $\mathrm{H}$ ru; PM; J 1747.

A. formosum Willd.; $\mathrm{H}$ ru; PM; A 738.

A. fragrans Sw.; H ep; LM; A 471, C 1289.

A. miradorense Liebm.; $\mathrm{H}$ ru te; PM; M 225.

A. salicifolium L.; H ep; LL; M 493.

A. serra Langsd. \& Fisch.; H ep; PM, LM; A 414, C 1321, 1373.

A. sessilifolium Desv.; $\mathrm{H}$ te; LM; C 1153.

A. uniseriale Raddi; $\mathrm{H}$ ru te; PM; A 771, M 186.

ATHYRIACEAE (1/4)

Diplazium altissimum (Jenman) C.Chr.; H te; LM; C 1196.

D. franconis Liebm.; H te; LM, UM; C 1126, 1152.

D. ternatum Liebm.; $\mathrm{H}$ te; PM, LM; A 380, J 1617.

Diplazium sp.; H te; PM; A 769, C 1738, J 1975, M 2925.

BLECHNACEAE (1/8)

Blechnum appendiculatum Willd.; H te; PM; M 2407, 2898.

* B. appendiculatum Willd. x occidentale L.; H te; LL, PM; M 1051, 1384.

B. divergens (Kunze) Mett.; H te; LL; M 652, 742.

B. ensiforme (Liebm.) C.Chr.; H cl te; PM, LM; C 1411, J 1986, M 1532, 2053.

B. falciforme (Liebm.) C.Chr.; H te; LM, UM; A 413, C 871.

B. schiedeanum (Schltdl. ex C.Presl) Hieron.; H te; LM; C 1220.

B. stoloniferum (Mett. ex E.Fourn.) C.Chr.; H ru; LM, UM; J 1725.

Blechnum sp.; H te; UM; C 1744. 
Appendix. Continuation.

CULCITACEAE (1/2)

Culcita coniifolia (Hook.) Maxon; H ru te; UM; C 1758.

Culcita sp.; H te; UM; J 1690.

CYATHEACEAE (3/9)

Alsophila salvinii Hook.; TF; LM; A 521, M 714.

Cnemidaria sp.; TF; PM; A 776.

Cyathea divergens Kunze var. tuerckheimii (Maxon) R.M.Tryon; TF; PM, LM; A 556, 613, 814,

C 1776, J 1660, M 1760, 1392.

C. fulva (M.Martens \& Galeotti) Fée; TF; PM, LM; C 1198, 1419, J 1455, M 1405.

C. cf. godmanii (Hook.) Domin; TF; PM; A 582.

C. myosuroides (Liebm.) Domin; TF; LL, PM; M 1052, 1181, 2879.

C. schiedeana (C.Presl) Domin; TF; LL, PM; A 742, C 1355, G 3739, J 1978, M 1998, 2124.

Cyathea sp. 1; TF; PM; G 3845.

Cyathea sp. 2; TF; PM; C 1396.

DENNSTAEDTIACEAE (3/7)

Dennstaedtia bipinnata (Cav.) Maxon; H he; LM; J 1614.

Hypolepis nigrescens Hook.; $\mathrm{H}$ te; PM; M 1558.

H. repens(L.) C.Presl; H te; LL, PM; M 1454, 2211.

Hypolepis sp.; $\mathrm{H}$ he; LM; G 3986.

Pteridium aquilinum (L.) Kuhn var. feei (W.Schaffn. ex Fée) Maxon ex Yunck.; H te; PM; M 2534.

P. arachnoideum (Kaulf.) Maxon; H te; LL; M 1283.

P. caudatum (L.) Maxon; H te; LL, PM; M 1017, 2325.

DICKSONIACEAE (2/2)

Dicksonia sellowiana Hook.; TF; UM; C 1214, J 1712.

Lophosoria quadripinnata (J.F.Gmel.) C.Chr.; H cl te; LM, UM; A 271, 440, C 874.

DRYOPTERIDACEAE (9/21)

Arachniodes denticulata (Sw.) Ching; H ru te; LM, UM; A 369, C 1084, 1204, 1759, J 1715, M 1554, 2924.

Bolbitis hastata (E.Fourn.) Hennipman; H te; PM; J 1985.

Ctenitis excelsa (Desv.) Proctor; H te; PM; M 1063, P 260.

C. hemsleyana (Baker) Copel.; H te; PM; A 774.

Dryopteris cinnamomea (Cav.) C.Chr.; $\mathrm{H}$ ru te; PM; M 188.

D. pseudofilix-mas (Fée) Rothm.; $\mathrm{H}$ te; PM; M 153.

D. wallichiana (Spreng.) Hyl.; H te; UM; C 1107, 1191, 1275.

日aphoglossum erinaceum (Fée) T.Moore var. erinaceum; H ep; PM, UM; J 1723, P 222.

E glaucum T.Moore; H ep; LM; C 1200.

E guatemalense (Klotzsch) T.Moore; H ep; LM; C 1201.

E peltatum (Sw.) Urb.; H ep; LM, UM; A 188, C 1216.

E petiolatum (Sw.) Urb.; H ep; LM; C 836 bis.

E sartorii (Liebm.) Mickel; H ep te; LM, UM; C 836, 1157, 1236, J 1694, M 753.

日aphoglossum sp.; H ep; LL; G 3749.

Lastreopsis effusa (Sw.) Tindale subsp. divergens(Willd. ex Schkuhr) Tindale; H te; LL; M 430, 477.

Phanerophlebia macrosora (Baker) Underw.; H te; UM; C 1108, J 1633.

Polystichum mickelii A.R.Sm.; H te; PM, LM; C 1195, 1347, 1394, M 1968.

Polystichum sp. 1; $\mathrm{H}$ te; UM; J 1728.

Polystichum sp. 2; $\mathrm{H}$ te; UM; C 1757.

Polystichum sp. 3; H ru; UM; J 1730.

Stigmatopteris longicaudata (Liebm.) C.Chr.; H te; PM, LM; C 1359, G 3885.

GLEICHENIACEAE (3/3)

Diplopterygium brancrofftii (Hook.) A.R.Sm.; H cl; LM; A 216, 474.

Gleichenella pectinata (Willd.) Ching; H te; LL, PM; M 1171, 2881.

Sticherus underwoodianus (Maxon) Nakai; H cl te; PM, UM; C 875, G 3953.

HYMENOPHYLLACEAE (1/2)

Hymenophyllum polyanthos (Sw.) Sw.; H ep; LM; C 1233.

Hymenophyllum sp.; H he; PM; J 1968. 
Appendix. Continuation.

LINDSAEACEAE $(2 / 2)$

Lindsaea arcuata Kunze; H ep te; PM; J 1664, M 1677.

Odontosoria schlechtendalii (C.Presl) C.Chr.; H te; PM; M 2413, 2514, 2880.

LOMARIOPSIDACEAE (1/1)

Nephrolepis sp.; H te; LM; A 566.

PLAGIOGYRIACEAE (1/1)

Plagiogyria pectinata (Liebm.) Lellinger; H te; UM; J 1724.

POLYPODIACEAE (12/26)

Campyloneurum amphostenon (Kunze ex Klotzsch) Fée; H ep; UM; C 1017.

C. phyllitidis(L.) C.Presl; H ep; LL, LM; C 1323, M 659.

C. tenuipes Maxon; H ep ru te; PM; M 279, 623, 2926.

C. xalapense Fée; H ep; PM; I 1648.

Ceradenia sp.; H ep; UM; C 1742, G 3970, J 1714.

Cochlidium linearifolium (Desv.) Maxon ex C.Chr.; H ep; LM, UM; C 1202, 1397.

C. serrulatum (Sw.) L.E.Bishop; H ep; LM, UM; C 1317, 1398.

Lellingeria prionodes (Mickel \& Beitel) A.R.Sm. \& R.C.Moran; H te; LM; C 1229.

Melpomene leptostoma (Fée) A.R.Sm. \& R.C.Moran; H te; LM; C 1230.

Niphidium crassifolium (L.) Lellinger; H ep ru te; PM; A 598, J 1525, 1743, M 1530, 2921, P 66.

Pecluma plumula (Humb. \& Bonpl. ex Willd.) M.G.Price; H ep; LL; M 687.

Phlebodium decumanum (Willd.) J.Sm.; H ep; LL; M 402.

P. pseudoaureum (Cav.) Lellinger; H ru te; PM; C 1775, G 3946, M 2895.

Pleopeltis angusta Humb. \& Bonpl. ex Willd.; H ru; PM; A 737.

P. mexicana (Fée) Mickel \& Beitel; H ep; LM; C 1234, 1769.

Polypodium echinolepis Fée; H te; PM; J 1649.

P. Iongepinnulatum E.Fourn.; H ep ru; PM, LM; C 1320, 1779, J 1750, M 1929, 2922.

P. muenchii Christ; H ep; PM, UM; C 1123, 1240, J 1648 bis.

P. plebeium Schltdl. \& Cham.; H cl ep; LL, PM, LM, UM; A 189, 319, C 1203, 1291, M 277, 655.

P. plesiosorum Kunze var. plesiosorum; H ep te; LM; UM; A 396, G 3976, J 1684, 2043, 2045.

P. pleurosorum Kunze ex Mett.; H cl ep; LM; C 1194.

P. puberulum Schltdl. \& Cham.; H ep; LM; C 920, 1724.

P. rhodopleuron Kunze; H ep te; LM; C 1288.

Polypodium sp.; H ep; LM; C 1723, 1736, 1959, G 3990.

Serpocaulon falcaria (Kunze) A.R.Sm.; H ep ru; PM, LM; A 412, 444, C 1737, G 3989, J 1746.

Terpsichore cultrata (Bory ex Willd.) A.R.Sm.; H ep; LM; C 1231.

PTERIDACEAE (5/7)

Eriosorus flexuosus (Kunth) Copel.; $\mathrm{H}$ te; UM; C 1212.

Pityrogramma ebenea (L.) Proctor; H te; PM, LM; A 355, 600.

Pteris biaurita L.; $\mathrm{H}$ te; PM; M 36.

P. quadriaurita Retz.; H te; PM; C 1362, M 2123.

Pteris sp.; H te; PM; C 1813, J 1970.

Scoliosorus ensiformis(Hook.) T.Moore; H ep; LM, UM; C 1048, J 1685.

Vittaria graminifolia Kaulf.; H ep; UM; C 955, 1273, J 1719, 1722.

SACCOLOMATACEAE $(\mathbf{1} / \mathbf{1})$

Saccoloma sp.; H te; LM; C 1718.

TECTARIACEAE (1/2)

Tectaria transiens (C.V.Morton) A.R.Sm.; H te; PM; M 167, 191.

Tectaria sp.; $\mathrm{H}$ te; PM; A 748.

THELYPTERIDACEAE $(2 / 7)$

Macrothelypteris torresiana (Gaudich.) Ching; H te; PM; M 1724, 1763, 2965.

Thelypteris dentata (Forssk.) E.P.St.John; H te; PM; M 1717, 2954.

T. meniscioides (Liebm.) C.F.Reed; H te; PM; M 1049, 2977, 2986, P 259.

T. pilosohispida (Hook.) Alston; $\mathrm{H}$ te; PM; M 662, 738.

T. reticulata (L.) Proctor; $\mathrm{H}$ te; PM; M 68, 150.

T. thomsonii (Jenman) Proctor; H te; PM; M 431, 524, 536.

Thelypterissp.; H te; PM; C 1396 bis. 
Appendix. Continuation.

\section{GYMNOSPERMS \\ CYCADIDAE}

ZAMIACEAE (2/2)

Ceratozamia whitelockiana Chemnick \& T.J.Greg.; CY; LM; A 516, P 312.

Dioon spinulosum Dyer; CY; LL; G 3881.

PINIDAE

PINACEAE (1/5)

Pinus chiapensis (Martínez) Andresen; T; PM, LM; A 3090, C 932, P 296, 300.

P. douglasiana Martínez; T; LM; C 1239.

* P. herrerae Martínez; T; LM, UM; A 513, C 1211, 1733.

P. patula Schltdl. \& Cham.; T; UM; C 809, 1760.

P. teocote Schltdl. \& Cham.; T; LM; A 512.

\section{PODOCARPACEAE (1/1)}

Podocarpus matudae Lundell; T; LM, UM; A 391, 400, 3081, C 864, 1026, G 4000, P 64.

TAXACEAE (1/1)

Taxus globosa Schltdl.; T; UM; A 211, 318, 3076, C 1122, J 1705, P 80.

\section{Angiosperms}

MAGNOLIIDAE

ANNONACEAE (7/10)

Annona liebmanniana Baill.; T; LL; G 3682, 3683, 3698, P 27.

* A. rensoniana (Standl.) H.Rainer; T; LL, PM; M 760, 1594, P 228.

A. reticulata L.; T; LL; M 2165.

* Cymbopetalum gracile R.E.Fr.; T; LL; G 3747.

Desmopsis Ianceolata Lundell; T; LL; J 1482.

Guatteria amplifolia Triana \& Planch.; T; PM; M 303, 2961.

G. galeottiana Baill.; T; PM; A 700, 749, C 1336, J 1595, P 17.

Rollinia sp.; T; PM; C 1381, J 1973.

Sapranthus sp.; T; LL, PM; G 3666, 3779.

Annonaceae 1; T; LL, PM; G 3661, 3766.

CHLORANTHACEAE (1/1)

Hedyosmum mexicanum C.Cordem.; T; PM, LM; A 247, G 3759, J 1447, P 31, 141.

LAURACEAE (7/33)

Beilschmiedia ovalioides Sa.Nishida; T; LM, UM; A 419, 433, 789, 790, C 904, 1007, 1158.

Cinnamomum areolatum (Lundell) Kosterm.; T; PM; A 697, 3132.

C. breedlovei (Lundell) Kosterm.; T; LM; J 1954.

C. zapatae Lorea-Hern.; T; LM, UM; A 301, C 1739, G 3996, J 1677, 1695, 1706, 1713.

Licaria cervantesii (Kunth) Kosterm.; T; PM; A 695, 712, J 1990.

L. chinanteca Lorea-Hern.; T; LM; C 1725, 1767, 1956.

L. excelsa Kosterm.; T; LM; A 530.

L. urceolata Lundell; T; PM; J 1988, P 122.

L. velutina van der Werff; T; LL; G 3696.

Litsea glaucescens Kunth; T; UM; C 1784.

Nectandra colorata Lundell; T; PM; P 215.

Ocotea acuminatissima (Lundell) Rohwer; T; PM, LM; A 366, 558, 570, 812, C 1352, 1393,

1780, 1960, 2176, P 7, 157.

O. bernoulliana Mez; T; PM; J 1962.

O. betazensis (Mez) van der Werff; T; LM, UM; A 257, 286, 294, 325, 427, 442, C 909, 1008, 1009, 1061, 1096, 1730.

O. bourgeauviana (Mez) van der Werff; T; PM, LM; A 527, J 1667.

O. chiapensis (Lundell) Standl. \& Steyerm.; T; LM; C 1284.

O. dendrodaphne Mez; T; PM; J 1451.

O. effusa (Meisn.) Hemsl.; T; PM, LM; A 375, C 834, 981, 992, 1079, 1089, 1325, 1719, G 3874.

O. helicterifolia (Meisn.) Hemsl.; T; PM; C 1811, P 216.

O. leucoxylon (Sw.) Laness.; T; PM; A 703, 3131, P 29, 286.

O. sarcodes Lorea-Hern.; T; LM, UM; A 545, 783, C 894, J 1953. 
Appendix. Continuation.

O. sauroderma Lorea-Hern.; T; LM; A 231, 493, 3094, C 1722, J 2050.

Ocotea sp.; T; PM; G 3794.

Persea albida Kosterm.; T; LM; A 552, 805.

P. americana Mill.; T; PM, LM, UM; A 180, 250, 272, 297, 711, C 898, 908, G 3971, 3973, J 1987.

P. chamissonis Mez vel aff.; T; UM; A 784, C 1332.

P. liebmannii Mez; T; PM, LM; A 551, 800, C 1418, 2185, P 13, 283.

P. obscura Lorea-Hern.; T; PM; A 3123.

P. pallescens (Mez) Lorea-Hern.; T; LM; A 524, C 1947, J 2053.

P. rufescens Lundell; T; LM; C 1948, J 2040, 2046, 2047.

P. schiedeana Nees; T; PM; P 151.

Lauraceae 1; T; LM; A 3162.

Lauraceae 2; T; PM; G 3727.

MAGNOLIACEAE (1/2)

Magnolia mexicana DC.; T; LL; J 1490.

M. schiedeana Schltdl.; T; LM, UM; A 337, 386, P 249.

MONIMIACEAE (1/2)

Mollinedia oaxacana Lorence; T; PM, LM; A 537, C 1356, 1392, G 3949, J 1582, 2066, M 80, 163, 1621.

M. viridiflora Tul.; T; PM, LM; A 518, 525, 560, C 1088, J 1732, M 1784, P 241.

\section{PIPERACEAE (2/54)}

Peperomia acuminata Ruiz \& Pav.; H ep te; PM, LM; A 306, 333, 454, 757, J 2061.

P. dendrophila Schltdl. \& Cham.; H ep ru; PM, LM; C 1293, 1395, J 1615, 1745.

* P. erythrostachya Trel.; H ep; LM, UM; A 395, 792, C 1120, 1147, 1238, G 3974.

P. glabella (Sw.) A.Dietr.; H ep te; PM, LM, UM; C 1292, J 1634, 1661, 1724 bis, 1982, P 149.

P. cf. granulosa Trel.; H te; UM; C 1399 bis.

P. hispiduliformis Trel.; $\mathrm{H}$ te; UM; C 1333.

P. Iancifolia Hook.; H te; PM; J 1739, M 2920, P 118.

P. obtusifolia (L.) A.Dietr.; H te; PM; M 311.

P. pellucida (L.) Kunth; $\mathrm{H}$ te; UM; C 1037.

P. peltilimba C.DC. ex Trel.; H ep; PM, LM; C 1358, J 1618.

P. petrophila C.DC.; H ep; PM; A 759.

P. quadrifolia (L.) Kunth; H ep; PM; A 777.

P. rotundifolia (L.) Kunth; H ep; PM; A 590.

P. tenerrima Schltdl. \& Cham.; H ep; LM; C 1295.

* P. tetraphylla Hook. \& Arn.; H ep; LM; C 1294.

* P. tovariana C.DC.; H te; LM; C 1237.

Peperomia sp. 1; $\mathrm{H}$ te; PM; C 1821.

Peperomia sp. 4; H ep; LM, UM; A 349, 397, J 1686.

Peperomia sp. 7; H ep; LM; C 1053, 1072.

Peperomia sp. 9; H ep; LM; A 434.

Peperomia sp. 11; H te; LM; A 305.

Peperomia sp. 12; H ep; LM; C 1296.

Peperomia sp. 13; H ep; LM; A 223, 480, C 1082.

Peperomia sp. 14; $\mathrm{H}$ te; LM; C 1092 bis.

Peperomia sp. 15; H ep; PM; G 3821.

Peperomia sp. 16; H ru; LL; J 1555.

Peperomia sp. 17; H ru; LL; J 1559.

Peperomia sp. 18; H ep; LL; J 1560.

Peperomia sp. 19; H ep; PM; J 1647.

Piper aequale Vahl; S; LL, PM; G 3796, 3862, M 376, 707, 1466.

P. amalago L.; S; PM; G 3848.

P. bredemeyeri J.Jacq.; S; LL; G 3664.

* P. chiquihuitense Trel. \& Standl.; S; UM; J 1621.

P. hispidum Sw.; S T; PM, LM, UM; A 287, 376, 448, 785, C 820, 902, 1013, 1215, 1354,

G 3812, J 2041, 2069, M 574.

* P. jalapense M. Martens \& Galeotti; S; PM; G 3707, 3815, 3824, J 1543. 
Appendix. Continuation.

P. marginatum Jacq.; S; LL; M 1061.

* P. maxonii C.DC.; S; PM; M 19, 335.

P. peltatum L.; H ep ru te; PM, LM, UM; A 330, 762, C 1387, J 1526, 1726, 1739.

* P. obliquum Ruiz \& Pav.; S T; PM, LM; G 3843, 3887, J 1506, 1738, 1956, M 1307, P 94, 225.

P. oradendron Trel. \& Standl.; S; LL; G 3795.

P. scabrum Lam.; S; LL; J 1542.

P. schiedeanum Steud.; S; PM; G 3822.

* P. tenuifolium C.DC.; S T; LL, PM; A 765, C 1338, G 3774, J 1463, 1980, M 1535.

P. umbellatum (L.) Miq.; S; PM; M 2481, P 261.

P. xanthostachyum C.DC.; H cl; LM; A 348, C 1071, 1300.

Piper sp. 1; T; PM; A 734.

Piper sp. 2; T; PM; C 1801.

Piper sp. 3; T; PM; C 1807.

Piper sp. 4; T; PM; C 1800.

Piper sp. 5; S; PM; P 110.

Piper sp. 6; S; PM; P 258.

Piper sp. 7; S; PM; G 3811.

Piper sp. 8; S; PM; G 3838.

Piper sp. 9; S T; PM; A 745, 766, C 1337, 1339, 1389, 1819, M 1344, 1389, P 224.

SIPARUNACEAE (1/2)

Siparuna gesnerioides (Kunth) A.DC.; T; LL, PM; C 1378, J 1638, M 512, 595, 1311, 2306.

S. thecaphora (Poepp. \& Endl.) A.DC.; S; LL, LM; J 1481, 1598, M 475, 773, 1033, 2989.

WINTERACEAE (1/1)

Drimys granadensis L.f. var. mexicana (Moc. \& Sessé ex DC.) A.C.Sm.; S T; PM, LM, UM; A 199, 445, C 876, 972, P 69.

\section{Eudicots}

\section{ACANTHACEAE (6/12)}

Aphelandra aurantiaca (Scheidw.) Lindl.; H te; LL, PM; C 1799, G 3743, P 253.

Msticia fimbriata (Nees) V.A.W.Graham; H S; LL, PM; G 3775, J 1546.

I pectoralis Jacq.; $\mathrm{H}$ te; PM; M 2917, 2932.

Usticia sp. 1; H te; LL; G 3741, 3742.

Msticia sp. 2; $\mathrm{H}$ te; PM; J 1528.

Louteridium mexicanum (Baill.) Standl.; T; LL, PM; G 3758, 3765.

Odontonema callistachyum (Schltdl. \& Cham.) Kuntze; S; PM, LM; A 225, 492, C 996, J 1580,

M 2935, P 251.

O. cuspidatum (Nees) Kuntze; S; LL, LM; G 3750, 3908, J 1640, 1641.

Schaueria parviflora (Leonard) T.F.Daniel; H te; LL; G 3700.

* Stenostephanus gracilis (Oerst.) T.F.Daniel; H te; PM; J 1527.

S. silvaticus (Nees) T.F.Daniel; S; PM; J 1593.

Acanthaceae 1; H te; PM; C 1809.

\section{ACTINIDIACEAE (1/8)}

Saurauia aspera Turcz.; T; PM; M 1848.

S. comitis-rossei R.E.Schult.; T; PM; A 707, P 155.

S. conzattii Buscal.; T; LL, LM, UM; A 249, 424, C 1041, 1310, M 1148.

S. leucocarpa Schltdl.; S T; LM; A 496, C 843, 1023.

S. pringlei Rose; T; PM; M 242.

S. scabrida Hemsl.; H te; PM; M 2391, 2988.

S. serrata DC.; T; LL, PM; G 3684, 3782, J 1497.

S. villosa DC.; T; LL, PM; G 3752, M 2948.

ADOXACEAE (2/6)

Sambucus nigra L. subsp. canadensis (L.) Bolli; S T; LM; A 387, C 1298.

* S. peruviana Kunth; T; PM; G 3833.

Viburnum acutifolium Benth. subsp. acutifolium; T; LM, UM; A 229, 239, 338, 3069, C 801, 861, 1762, J 1632, 1678.

V. acutifolium Benth. subsp. blandum C.V.Morton; T; UM; A 3114, G 3984. 
Appendix. Continuation.

V. hartwegii Benth.; T; LM; A 3109, C 850, 990, 991, 1133, 1407, P 71.

V. sulcatum (Oerst.) Hemsl.; S; UM; C 1132, 1139.

ALTINGIACEAE (1/1)

Liquidambar styraciflua L.; T; PM; A 191, G 3945, M 542, 2870.

AMARANTHACEAE (2/2)

Iresine diffusa Humb. \& Bonpl. ex Willd.; H te; LL; M 698, 2946.

Pederseniasp.; L; PM; C 1822.

ANACARDIACEAE (2/2)

Spondias radlkoferi Donn.Sm.; T; PM; P 227.

Tapirira sp.; T; PM; A 778.

APIACEAE (3/3)

Arracacia molseedii Mathias \& Constance; H te; UM; C 1255.

Eyngium scaposum Turcz.; H te; UM; C 1247.

Ottoa oenanthoides Kunth; $\mathrm{H}$ te; UM; C 1276.

APOCYNACEAE (6/8)

Mandevilla subsagittata (Ruiz \& Pav.) Woodson; H cl; LL, PM; M 2139, 2351, 2594.

Marsdenia Iaxiflora Donn.Sm.; H cl; LL; J 1548.

M. rzedowskiana Juárez-Jaimes \& W.D.Stevens; H cl; LM; A 354.

Oxypetalum cordifolium (Vent.) Schltr.; H cl; PM; M 2904.

Prestonia mexicana A.DC.; L; PM; M 219, P 270.

Tabernaemontana littoralis Kunth; T; LL; G 3797.

Thevetia ahouai (L.) A.DC.; S; PM; M 2045.

Apocynaceae 1; $\mathrm{H} \mathrm{cl}$; PM; C 1372.

AQUIFOLIACEAE (1/2)

Ilex pringlei Standl.; S T; PM, UM; A 209, 322, C 1125, 1258, 1773.

I. tolucana Hemsl.; T; PM; A 701.

ARALIACEAE $(2 / 7)$

Dendropanax arboreus (L.) Decne. \& Planch.; T; LL, PM, LM, UM; A 273, 282, 283, 342, 447, C 872, 1184, G 3771, J 1639, 1687, 1698, M 179, 512.

* D. capillaris M.J.Cannon \& Cannon; T; LL; J 1539A.

D. populifolius (Marchal) A.C.Sm.; T; LM; A 215, C 960, 1000, 1057.

D. stenodontus (Standl.) A.C.Sm.; T; PM, LM; A 595, 743, C 1314, 1817, 1818, G 3770,

J 1594, P 97.

Oreopanax capitatus (Jacq.) Decne. \& Planch.; T; LL, LM, UM; A 237, 244, 422, C 798, 891, G 3706, 3710.

O. flaccidus Marchal; T; LM, UM; A 275, C 1004.

O. xalapensis (Kunth) Decne. \& Planch.; T; PM, LM, UM; C 852, 892, J 1507.

ASTERACEAE (36/68)

Achyrocline deflexa B.L.Rob. \& Greenm.; $\mathrm{H}$ te; LM; C 819.

Ageratina ligustrina (DC.) R.M.King \& H.Rob.; T; UM; A 312, 321, C 802, 814, 895, 944, 1247 bis, 1754.

A. lucida (Ortega) R.M.King \& H.Rob.; H te; PM; M 2354.

A. pichinchensis (Kunth) R.M.King \& H.Rob.; H S; UM; C 1032, G 3983.

Ageratina sp. 1; $\mathrm{H}$ te; UM; C 1266.

Ageratina sp. 2; $\mathrm{H}$ te; UM; C 1250.

Ageratina sp. 3; S; UM; C 897.

Alloispermum integrifolium (DC.) H.Rob.; H te; PM; M 2942.

Archibaccharis trichotoma (Klatt) G.L.Nesom; H S; UM; C 812, 1244, 1751, 1782.

Baccharis conferta Kunth; T; UM; A 341.

B. trinervis Pers.; $\mathrm{H}$ te; PM; M 584.

Bartlettina calderonii (B.L.Turner) B.L.Turner; T; LM; A 368, 539, J 1619, 1626.

B. constipatiflora (Klatt) R.M.King \& H.Rob.; S; UM; A 198, C 1328, 1734.

B. macdougallii R.M.King \& H.Rob.; S; LM; G 3988.

B. platyphylla (B.L.Rob.) R.M.King \& H.Rob.; H te; PM; M 341.

B. sordida (Less.) R.M.King \& H.Rob.; T; UM; A 367.

B. tuerckheimii (Klatt) R.M.King \& H.Rob.; S; PM, UM; C 1206, M 559. 
Appendix. Continuation.

Bartlettina sp. 1; $\mathrm{H} \mathrm{cl} ;$ UM; A 279.

Bartlettina sp. 2; T; LM, UM; A 431, C 922, 1002, 1030, G 3987.

Bidens triplinervia Kunth; $\mathrm{H}$ te; UM; C 1248.

Chionolaena eleagnoides Klatt; H te; UM; C 1252, 1263, 1788.

C. salicifolia (Bertol.) G.L.Neson; H te; UM; C 1036, 1249.

Clibadium arboreum Donn.Sm.; S; LL, PM; M 2145, 2598.

Critonia sexangularis(Klatt) R.M.King \& H.Rob.; S; LL, PM; M 91, 969.

Critonia sp.; S; LL; J 1547.

Eephantopus mollis Kunth; H te; PM; M 2943.

Feischmannia pycnocephala (Less.) R.M.King \& H.Rob.; H te; PM; M 2875, 2944.

Galinsoga parviflora Cav.; $\mathrm{H}$ te; PM; M 63, 2359.

Gamochaeta americana (Mill.) Wedd.; H te; LM; A 252.

Hidalgoa ternata La Llave; H cl; LL; J 1553.

Jaegeria hirta (Lag.) Less.; $\mathrm{H}$ te; UM; J 1631.

Koanophyllon sp.; T; PM; A 768, C 1803, J 1556.

Lepidaploa salzmanii (DC.) H.Rob.; H te; PM; J 1992, M 151.

Mikania gonzalezii B.L.Rob \& Greenm.; H cl; LM; A 441.

M. micrantha Kunth; $\mathrm{H}$ cl; PM; M 1449.

M. pyramidata Donn.Sm.; L; PM, LM, UM; C 810, 910, M 892.

M. tonduzii B.L.Rob.; $\mathrm{H} \mathrm{cl}$; LM; C 1287.

Mikania sp.; L; PM; A 3125.

Neomirandea araliifolia (Less.) R.M.King \& H.Rob.; T; PM; M 158.

Neurolaena lobata (L.) Cass.; T; PM; C 1361, J 1958, M 2884.

Oxylobus oaxacanus S.F.Blake; H S; UM; C 1267, 1787.

Pentacalia parasitica (Hemsl.) H.Rob. \& Cuatrec.; L; UM; A 207, C 857, G 3978.

Pseudognaphalium liebmannii (Sch.Bip. ex Klatt) Anderb.; H te; UM; C 1251.

P. semilanatum (DC.) Anderb.; H te; UM; A 248, C 1750.

Roldana anisophylla (Klatt) Funston; H S; UM; A 206, C 1280, 1781.

R. Ianicaulis (Greenm.) H.Rob. \& Brettell; H S; LM, UM; C 1329, 1746, 1755, G 3982.

R. oaxacana (Hemsl.) H.Rob. \& Brettell; H te; LM, UM; A 280, C 1745.

Schistocarpha bicolor Less.; H te; PM, LM; C 1814, G 3991.

S. platyphylla Greenm.; H te; PM; M 1804.

Schistocarpha sp.; S; LM; C 1047.

Senecio polypodioides (Greene) T.Durand \& B.D.Jacks.; H te; UM; A 205, C 1243, 1753, 1832.

Sigesbeckia jorullensis Kunth; $\mathrm{H}$ te; UM; C 1245.

Sinclairia deppeana (Less.) Rydb.; H cl; LM; C 1286.

S. discolor Hook. \& Arn.; H te; PM; M 1827.

S. polyantha (Klatt) Rydb.; H ep; LL, PM; C 1805, J 1554, 1557, 1966, 1984.

Stevia microchaeta Sch.Bip.; H S; LM, UM; A 285, C 813.

Stramentopappus pooleae (B.L.Turner) H.Rob. \& V.A.Funk; S T; LM, UM; A 259, 462, C 1005, 1335, G 3964.

Telanthophora andrieuxii (DC.) H.Rob. \& Brettell; H S; LM, UM; C 1735, 1752.

T. grandifolia (Less.) H.Rob. \& Brettell var. grandifolia; S T; LL, PM, LM; A 401, G 3876, J 1573, M 1106, 1253, 2975.

T. liebmannii (Buchinger ex Klatt) H.Rob. \& Brettell; S T; LM; A 181, 791.

T. uspantanensis (J.M.Coult.) H.Rob. \& Brettell; H te; LM; C 818.

Tithonia longiradiata (Bertol.) S.F.Blake; H te; PM; M 2933.

Trigonospermum melampodioides DC.; H te; PM; M 2909.

Verbesina intermissa S.F.Blake; $\mathrm{H}$ te; UM; C 1241.

V. turbacensis Kunth; H te; PM; M 2635.

Vernonanthura patens (Kunth) H.Rob.; T; PM; G 3954, M 2991, 2945, P 49.

Asteraceae 1; T; PM; C 1368.

Asteraceae 2; L; PM; A 3142.

BALANOPHORACEAE (1/1)

Helosis cayennensis (Sw.) Spreng.; H te; LM; C 1024, 1154. 
Appendix. Continuation.

BALSAMINACEAE (1/1)

Impatiens walleriana Hook.f.; $\mathrm{H}$ te; PM; M 2928.

BEGONIACEAE (1/14)

Begonia glabra Aubl.; H cl ep; LL, PM; C 1357, 1798, J 1561, M 294, P 268.

B. Iudicra A.DC.; H te; PM; M 2929, 2971.

B. manicata Brong. ex F.Cels; H ru; LL; J 1569.

B. nelumbiifolia Schltdl. \& Cham.; H te; PM; M 2519, 2979, P 129.

B. oaxacana A.DC.; H te; LM; A 327, 389.

* B. parviflora Poepp. \& Endl.; H ru te; LL, PM; G 3686, J 1521.

B. rafael-torresii Burt-Utley; H te; PM; M 37, 450, 2950.

Begonia sp. 1; $\mathrm{H}$ te; PM; A 767, C 1797.

Begonia sp. 2; H ep ru te; PM, LM; C 1374, J 1613, 1742, 1971.

Begonia sp. 3; H ru; LL; G 3701.

Begonia sp. 4; H ep; PM; J 1499.

Begonia sp. 5; $\mathrm{H}$ ru; PM; J 1741.

Begonia sp. 6; H ru; PM; J 1972.

Begonia sp. 7; $\mathrm{H}$ te; PM; P 105.

BIGNONIACEAE (5/7)

Amphitecna macrophylla (Seem.) Miers ex Baill.; T; LL, PM, LM; C 1312, G 3943, M 771.

Amphitecna sp.; T; PM; G 3829.

Cydista aequinoctialis(L.) Miers var. aequinoctialis, $\mathrm{H}$ cl; PM; M 1783.

Clytostoma binatum (Thunb.) Sandwith; L; LL; G 3802.

Distictis laxiflora (DC.) Greenm.; L; PM; M 1866.

Macfadyena unguis-cati (L.) A.H.Gentry ; L; PM; M 2483.

Bignoniaceae 1; L; PM; P 256.

BORAGINACEAE (3/4)

Cordia stellifera I.M.Johnst.; T; PM; M 2377.

Varronia spinescens (L.) Borhidi ; H te; PM; M 2596.

* Wigandia urens (Ruiz \& Pav.) Kunth; H te; PM; G 3956.

Boraginaceae 1; S; PM; P 107.

BRASSICACEAE (1/1)

Cardamine fulcrata Greene; $\mathrm{H}$ te; LM; A 331.

BRUNELLIACEAE (1/1)

Brunellia mexicana Standl.; T; PM, LM; C 1304, M 1301, 2089, 2990.

BURSERACEAE (1/1)

Protium copal (Schltdl. \& Cham.) Engl.; T; PM; A 193, 612, C 1351, J 1589, M 1903, P 28.

CACTACEAE (3/3)

Disocactus ackermannii (Haw.) Ralf Bauer; H ep; LM; A 411, C 1012 bis.

Pseudorhipsalis ramulosa (Salm-Dyck) Barthlott; H ep; LM; C 1297.

Rhipsalis baccifera (J.S.Muell.) Stearn; H ep; PM; P 63.

CAMPANULACEAE (1/2)

Centropogon cordifolius Benth.; H te; LM; C 934.

C. grandidentatus (Schltdl.) Zahlbr.; S; LM; A 183.

CANNABACEAE (2/2)

Lozanella enantiophylla (Donn.Sm.) Killip \& C.V.Morton; T; LM, UM; A 251, 303, 343, 425, C 1028.

Trema micrantha (L.) Blume; T; PM; G 3958, M 2443, P 2.

CAPPARACEAE (1/1)

Capparidastrum mollicellum (Standl.) Cornejo \& Iltis; S; PM; J 1596, P 96.

CAPRIFOLIACEAE (1/1)

Valeriana scandens L.; $\mathrm{H}$ cl; UM; C 954, 1031.

CARICACEAE (1/1)

Carica cnidoscoloides Lorence \& R.Torres; T; PM; G 3730, 3734, 3863, J 1597, 1656, M 2972, P 165.

CARYOPHYLLACEAE (1/1)

Arenaria bourgaei Hemsl.; H te; UM; C 905. 
Appendix. Continuation.

CELASTRACEAE (7/7)

Celastrus vulcanicola Donn.Sm.; L; LM, UM; A 182, 202, 429, 435, C 889, 1124, G 3977. Crossopetalum parviflorum (Hemsl.) Lundell; T; PM; G 3767.

Quetzalia occidentalis (Loes. ex Donn.Sm.) Lundell; T; LM; A 230, 526, J 2052.

Quetzalia sp.; T; LM; C 1950.

* Salacia cordata (Miers) Mennega; L; PM, LM; M 1658, P 53, 212, 291.

Wimmeria bartlettii Lundell; T; PM; G 3872.

Zinowiewia sp.; T; PM, LM; A 485, C 1957, P 299.

CHRYSOBALANACEAE (1/1)

Couepia polyandra (Kunth) Rose; T; PM; P 233.

CLEOMACEAE (1/1)

Cleome sp.; S; PM; P 242.

CLETHRACEAE (1/6)

Clethra conzattiana L.M.González; T; LM, UM; A 186, 258, 399, C 886, 1099, 1743.

C. galeottiana Briq.; T; UM; A 276, C 855, 1210.

C. integerrima (Turcz.) L.M.González; T; PM; A 610, J 1584, 1674.

C. kenoyeri Lundell; T; LM; C 911, 1766.

C. Iuzmariae L.M.González; T; UM; C 1268, 1279, 1790.

C. mexicana DC.; T; LL, PM; M 1147, 2892.

CLUSIACEAE (4/7)

Clusia guatemalensis Hemsl.; T ep he te; PM, LM; A 195, C 912, 1826, G 3864.

C. Iundellii Standl.; T ep te; LM; A 240, 500, 517, 547, 548, 713, 801, 3098, C 988, G 3969, J 2056.

C. quadrangula Bartlett; T he; LL; G 3753.

C. salvinii Donn.Sm.; S; PM, LM; A 563, 698, C 835, P 75.

Garcinia intermedia (Pittier) Hammel; T; LL, PM; C 1346, G 3692, 3959, J 1974, M 160, 2025, P 40, 211, 274, 290.

* Hypericum pratense Schltdl. \& Cham.; H te; PM, UM; C 1208, M 2876.

Vismia baccifera (L.) Triana \& Planch.; T; PM; M 1849, P 5.

COMBRETACEAE $(2 / 2)$

Combretum fruticosum (Loefl.) Stuntz; L; LL; J 1475.

Terminalia amazonia (J.F.Gmel.) Exell; T; PM; M 1350, P 44, 131.

CONVOLVULACEAE $(2 / 2)$

Merremia tuberosa (L.) Rendle; H cl; LL; J 1549.

Convolvulaceae 1; $\mathrm{H} \mathrm{cl}$; LL; P 265.

CORNACEAE (1/1)

Cornus disciflora Moc. \& Sessé ex DC.; T; LM, UM; A 278, 415, C 804, 890, 941, 1209.

CUCURBITACEAE (5/6)

Hanburia mexicana Seem.; H cl; LL, PM; G 3703, 3950, P 18.

Melothria pendula L.; $\mathrm{H}$ cl; PM; M 2938.

Psiguria triphylla (Miq.) C.Jeffrey; L; PM; G 3879, P 104.

Sechium chinantlense Lira \& F.Chiang; H cl; LL; G 3702.

Sicyos galeottii Cogn.; H cl; LM, UM; A 197, C 815, 893.

Sicyos sp.; H cl; LM; UM; A 457, C 1190.

CUNONIACEAE (1/2)

* Weinmannia balbisiana Kunth; T; UM; A 203, 339, 465, 466, G 3975.

W. pinnata L.; T; LM, UM; C 903, 1011, 1098.

CYRILLACEAE (1/1)

Cyrilla racemiflora L.; T; PM, LM; A 807, 3108, C 1408, J 2055, P 136, 158.

DILLENIACEAE (1/1)

Doliocarpus dentatus (Aubl.) Standl. subsp. dentatus, T; PM; M 2669.

DIPENTODONTACEAE (1/1)

Perrottetia longistylis Rose; T; LL, PM, LM; A 302, 455, 708, 735, C 1045, G 3705, J 1524,

M 235, P 213, 272.

EBENACEAE (1/1)

* Diospyros nigra (J.F.Gmel.) Perr.; T; PM; A 194. 
Appendix. Continuation.

ERICACEAE (13/18)

Agarista mexicana (Hemsl.) Judd var. mexicana; T; PM; A 3083, C 1827, P 47.

Arctostaphylos sp.; S; UM; C 1253.

Bejaria aestuans Mutis ex L.; T; PM, LM; A 241, 475, 504, 549, C 1405, J 1673, P 54, 278.

Cavendishia bracteata (Ruiz \& Pav. ex J.St.-Hil.) Hoerold; S ep; LM, UM; A 436, C 799, 913, J 1575.

Cavendishia sp.; S ep; UM; J 1710.

Chimaphila umbellata (L.) W.P.C.Barton subsp. umbellata; H te; UM; A 323, C 1131.

Comarostaphylis discolor (Hook.) Diggs; T; UM; C 1130, 1142, 1261.

Gaultheria erecta Vent.; S T; LM, UM; A 190, 212, 311, C 800, 805, 862, 950, 1246, J 1703.

Lyonia squamulosa M.Martens \& Galeotti; T; PM, LM; A 227, 554, C 921, 924, M 2958.

Macleania insignis M.Martens \& Galeotti; S ep te; PM, LM; A 235, 580, 758, C 849, 914, 1003, G 3837, J 1662, 1676.

Monotropa uniflora L.; H te; PM, UM; C 1129, P 294.

Satyria panurensis (Benth. ex Meisn) Hook.f ex Nied.; T; LL, PM, UM; G 3711, J 1450, M 2962.

* Sphyrospermum cordifolium Benth.; S ep; LM; C 1290.

Vaccinium consanguineum Klotzsch; T; PM; LM, UM; A 483, 505, C 887, 1033, 1043, 1134,

1146, J 1717, P 72.

V. cordifolium (M.Martens \& Galeotti) Hemsl.; S ep te; LM, UM; A 417, C 869.

Ericaceae 1; S; UM; C 1254.

Ericaceae 2; S; UM; C 1272.

Ericaceae 3; S; UM; C 1257.

ERYTHROXYLACEAE (1/1)

Erythroxylum macrophyllum Cav.; T; LL; M 1082.

EUPHORBIACEAE (8/13)

Acalypha macrostachya Jacq.; S; PM; M 1794, 1865.

A. skutchii I.M.Johnst.; S; PM; G 3869.

Alchornea latifolia Sw.; T; PM, LM; C 1067, 1302, J 1574, M 13, 2883, P 56.

Alchornea sp.; T; PM; A 609, 3163, J 1665, P 35.

Cleidion sp.; T; PM; A 3146.

Cnidoscolus multilobus (Pax) I.M.Johnst.; S; PM; M 100.

Croton draco Schltdl. \& Cham.; T; LL, PM; M 429, 716, P 1.

C. macrodontus Müll.Arg; T; LL; G 3737.

C. xalapensis Kunth; T; PM; M 2882.

Euphorbia finkii (Boiss.) V.W.Steinm.; H te; LL, PM; G 3672, J 1551.

E orizabae Boiss.; S; UM; C 953, 1259, 1711.

Hieronyma oblonga (Tul.) Müll.Arg.; T; PM; A 702, 704, P 219.

Plukenetia carabiasiae J.Jiménez Ram.; L; LL; G 3757, J 1550.

FAGACEAE (1/7)

Quercus corrugata Hook.; T; LM, UM; A 298, 299, 420, 482, 3096, P 250.

Q. elliptica Née; T; PM; A 3086, 3087, C 1831, P 58, 232.

Q. glaucescens Humb. \& Bonpl.; T; PM; A 3088.

Q. macdougallii Martínez; S; UM; C 1270.

Q. nixoniana S.Valencia \& Lozada-Pérez; T; LM; C 993.

*Q. trinitatis Trel.; T; UM; A 461, C 1112, 1144, G 3972.

Quercussp.; T; LM; A 503, 3092, C 1727.

GELSEMIACEAE (1/1)

* Gelsemium sempervirens (L.) J.St.-Hil.; H cl; PM; J 1663.

GENTIANACEAE (3/3)

Chelonanthus alatus (Aubl.) Pulle; H te; PM; M 2872.

Gentiana ovatiloba Kusn. subsp. ovatiloba; H te; UM; C 1269.

Voyria parasitica (Schltdl. \& Cham.) Ruyters \& Maas; H te; LL; J 1467.

GESNERIACEAE (7/7)

Achimenes grandiflora (Schiede) DC.; H te; LL; P 237.

Besleria laxiflora Benth.; H te; PM; M 2119, 2973.

Columnea schiedeana Schltdl.; H ep; LL, PM; A 593, G 3860, 3866, J 1540.

Drymonia sp.; H ep; LM; A 3095. 
Appendix. Continuation.

Moussonia deppeana (Schltdl. \& Cham.) Hanst.; H te; LL, PM, LM; C 1305, 1379, M 1259, 1341. Smithiantha multiflora (M.Martens \& Galeotti) Fritsch; H ru; LL; G 3685.

Solenophora insignis (M.Martens \& Galeotti) Hanst.; S; LM; A 326, 456.

GUAMATELACEAE (1/1)

Guamatela tuerckheimii Donn.Sm.; H te; PM; P 279.

ICACINACEAE (2/2)

Calatola costaricensis Standl.; T; LM; A 538, G 3897.

Oecopetalum mexicanum Greenm. \& C.H.Thomps.; T; LL; G 3667.

JUGLANDACEAE (3/3)

Alfaroa mexicana D.E.Stone; T; LM; A 546.

Mglans pyriformis Liebm.; T; PM; G 3875, J 1537.

Oreomunnea mexicana (Standl.) J.F.Leroy subsp. mexicana; T; LM; A 528, C 928, 982.

LACISTEMATACEAE (1/1)

Lacistema aggregatum (P.J.Bergius) Rusby; T; PM; P 46.

LAMIACEAE (3/3)

Hyptis atrorubens Poit.; $\mathrm{H}$ te; PM; M 2459, 2552.

Salvia recurva Benth.; $\mathrm{H}$ te; LM, UM; C 856, 1156.

Stachys sp.; H cl; UM; A 260.

LEGUMINOSAE (17/28)

Ateleia pterocarpa Moc. \& Sessé ex D.Dietr.; T; PM; P 263.

Calliandra grandiflora (L'Hér.) Benth.; S; LL; M 2146, 2229.

C. houstoniana (Mill.) Standl.; S; PM; M 2509.

Centrosema pubescens Benth.; L; PM; M 2601, 2614.

Desmodium adscendens(Sw.) DC.; H te; PM; M 1128.

D. cinereum (Kunth) DC.; S; PM; M 2499.

* Eythrina rubrinervia Kunth; T; PM; M 2887.

Eythrina sp. 1; T; PM; C 1810.

Eythrina sp. 2; T; PM; J 1512.

Inga acrocephala Steud.; T; LL, PM; A 597, G 3948, J 1583, 1979, M 164, 379, P 230.

I. flexuosa Schltdl.; T; LM; A 540.

I. oerstediana Benth.; T; PM; G 3877.

I. pavoniana G.Don; T; LL, PM; M 128, 571, 1250, P 32.

I. tuerckheimii Pittier; T; PM; M 85.

Lonchocarpus robustus Pittier; T; LL; J 1476.

Machaerium floribundum Benth.; L; LL; M 639.

Mimosa albida Humb. \& Bonpl. ex Willd.; S; LL, PM; M 1265, 1791, 2940.

* M. hondurana Britton; S; PM; M 2096.

M. somnians Humb. \& Bonpl. ex Willd.; S; LL; M 1236.

Mucuna argyrophylla Standl.; L; PM; P 26.

Rhynchosia erythrinoides Schltdl. \& Cham.; L; PM; M 604, 1328, 1806.

Senegalia hayesii (Benth.) Britton \& Rose; L; PM; G 3861.

Senna multijuga (Rich.) H.S.Irwin \& Barneby subsp. doylei (Britton \& Rose) H.S.Irwin \& Barneby;

T; LL; M 962, 1079.

S. pallida (Vahl) H.S.Irwin \& Barneby var. lemniscata H.S.Irwin \& Barneby; T; LL; J 1489.

Swartzia mexicana M.Sousa \& R.Grether; T; PM; A 607, 3126, M 1616, P 37, 142, 152.

Teramnus labialis (L.f.) Spreng.; H te; PM; M 2659.

Vigna umbellata (Thunb.) Ohwi \& H.Ohashi; H cl; LL; G 3677.

* Zygia longifolia (Humb. \& Bonpl.) Britton \& Rose; T; LL; G 3799, 3800.

LENTIBULARIACEAE (1/1)

Pinguicula hemiepiphytica Zamudio \& Rzed.; H ep te; LM; A 358, 410, 418, 477, C 1075, G 3999.

LOGANIACEAE (1/2)

Strychnos panamensis Seem. var. hirtiflora Standl.; L; LL; J 1564.

S. panamensis Seem. var. panamensis, L; PM; P 210.

LORANTHACEAE (2/2)

Psittacanthus ramiflorus (Moc. \& Sessé) G.Don; S ep; PM; J 1753. 
Appendix. Continuation.

Struthanthus deppeanus (Schltdl. \& Cham.) D.Don; S ep; LM; C 1406.

MALPHIGIACEAE (5/6)

Bunchosia lindeniana A.Juss.; T; PM, LM; G 3901, 3952, J 1529, M 292, 1907.

B. nitida (Jacq.) DC.; T; PM; G 3718.

Heteropteris macrostachya A.Juss.; L; LL; J 1477.

Malpighia glabra L.; T; LL; G 3699, J 1471.

Mascagnia sp.; L; PM; P 119.

Tetrapterys schiedeana Schltdl. \& Cham.; L; PM; P 273.

MALVACEAE (13/17)

Hampea sp.; T; PM; J 1500.

* Helicteres guazumifolia Kunth; S; LL; M 1012, 1095.

Heliocarpus appendiculatus Turcz.; T; LL, PM, LM; C 1307, J 1545, 1566, M 232, 631, P 85.

H. donnellsmithii Rose; T; LL, PM; M 930, 2135.

Hibiscus costatus A.Rich.; $\mathrm{H}$ te; PM; M 2871.

H. uncinellus DC.; H te; LL, PM; J 1544, M 1160, 2985.

Luhea speciosa Willd.; T; LL; P 244.

Malvaviscus arboreus Cav.; S; LL, PM; G 3662, 3731, 3788.

Mortoniodendron hirsutum Standl.; T; LL; G 3689, 3693, 3746, J 1459.

Mortoniodendron sp.; T; LL; G 3697.

Pachira aquatica Aubl.; T; PM; P 100.

* Pavonia schiedeana Steud.; H te; LL; G 3883.

Quararibea yunckeri Standl. subsp. sessiliflora Miranda ex W.S.Alverson; T; LL; G 3787.

Sida rhombifolia L.; H te; LL, PM; G 3884, M 2934.

Trichospermum galeottii (Turcz.) Kosterm.; T; LL; P 229.

T. mexicanum (DC.) Baill.; T; LL, PM; M 457, 1032, 1116, 2078.

Triumfetta grandiflora Vahl; S; PM, LM; C 1282, M 301, 342.

MARCGRAVIACEAE (1/1)

Marcgravia stonei Utley; L; PM, LM; J 1610, P 132.

MELASTOMATACEAE (9/39)

Arthrostemma ciliatum Pav. ex D.Don; H te; PM; C 1380, M 2873, 2941, P 311.

Clidemia dentata Pav. ex D.Don; H te; LL; M 984, 2152.

C. gracilipes Gleason; T; PM, LM; C 1068, G 3849, J 1625.

C. hirta (L.) D.Don; $\mathrm{H}$ te; PM; M 2890.

C. setosa (Triana) Gleason; H te; LL, PM; G 3745, 3772.

Conostegia caelestis Standl.; T; LL, PM; G 3736, 3773, J 1522, M 1249, 2891.

C. icosandra (Sw. ex Wikstr.) Urb.; T; PM; A 733, J 1749, M 2382.

C. xalapensis (Bonpl.) D.Don ex DC.; S; LL, PM; M 1110, 2903.

Heterocentron subtriplinervium (Link \& Otto) A.Braun \& C.D.Bouché; H te; LL, PM; M 2253, 2276, 2352.

Miconia anisotricha (Schltdl.) Triana; S; UM; C 1135.

M. argentea (Sw.) DC.; T; LL; M 967.

M. chrysoneura Triana; S T; LM; A 219, 352, C 998, 1021, 1059, 1151.

M. costaricensis Cogn.; S T; LM; A 370, 385, C 963.

M. dodecandra Cogn.; T; PM; G 3762, J 1445.

M. fulvostellata L.O.Williams; T; PM; G 3828.

M. glaberrima (Schltdl.) Naudin; S T; PM, LM, UM; A 185, 201, 213, 214, 236, 254, 284, 381, $382,403,408,439,459,501,604,3080,3102, C$ 807, 827, 879, 930, 931, 967, 977, 1014, 1055, 1066, 1145, 1149, 1221, G 3957, J 1693.

M. globulifera Naudin; S; PM; A 710.

M. gracilis Triana; T; LL; M 414.

M. hemenostigma Naudin; S T; PM, LM, UM; A 253, 336, 3070, C 808, 906, 907, 937, 1015, 1213, G 3963.

M. ibaguensis(Bonpl.) Triana; T; PM; C 1825, M 2893.

M. impetiolaris (Sw.) D.Don ex DC.; T; LL; G 3803.

M. laevigata (L.) D.Don; T; LL, PM; M 727, 1708, P 42.

M. liebmannii Cogn.; S T; LM; C 838, 1054, 1421. 
Appendix. Continuation.

M. Ionchophylla Naudin; T; PM, LM; A 536, 781, C 997, 1056, 1065, 1090, 1092, 1313, 1367, J 1624, 1642.

M. minutiflora (Bonpl.) DC.; T; LL; M 1071.

M. prasina (Sw.) DC.; T; LL; M 382, 749, 766.

M. serrulata (DC.) Naudin; T; LL, PM; M 986, 2259, P 154.

M. Smaragdina Naudin; T; PM; C 1824.

M. trinervia (Sw.) D.Don ex Loudon; T; PM, LM; C 1385, J 1989, M 1572, 1579, 1611, P 55.

M. tuerckheimii Cogn.; S; LM, UM; A 184, 404, 3071, C 806, 880, 1185, J 2070, 2071.

Miconia sp. 1; T; LM; C 975, 1046, 1148.

Miconia sp. 2; S; UM; A 308, 309, C 951, 952, 1136, 1137, 1756.

Miconia sp. 3; T; PM, LM; A 755, C 1283, G 3961, J 1578, 1981.

Miconia sp. 4; S; UM; J 1696.

Monochaetum alpestre Naudin; S; LM, UM; C 853, 1242.

M. pulchrum Decne.; $\mathrm{H}$ te; LM; C 1303.

Ossaea micrantha (Sw.) Macfad. ex Cogn.; T; PM; G 3725.

Tibouchina scabriuscula (Schltdl.) Cogn.; S; LM, UM; C 860, 1228.

Topobea laevigata (D.Don) Naudin; T ep he; LL, PM, LM; C 1281, G 3754, J 1532.

MELIACEAE (2/5)

Guarea glabra Vahl; T; LL, PM; J 1959, M 517, 780, 2087, P 115, 128.

G. grandifolia DC.; T; PM; M 1904, 2027.

Trichilia martiana C.DC.; T; PM; G 3728.

T. moschata Sw.; T; LL; J 1479.

Trichilia sp.; T; LM; A 3111, 3160.

MENISPERMACEAE (3/4)

Abuta panamensis (Standl.) Krukoff \& Barneby; L; PM; M 2029, P 226, 262.

Cissampelos pareira L.; H cl; PM; M 903, 1826, 1897, 2952.

C. tropaeolifolia DC.; $\mathrm{H}$ cl; PM; M 1725, 1899.

Disciphania calocarpa Standl.; L; LL, PM; G 3777, J 1462.

MORACEAE (3/8)

Ficus apollinaris Dugand; T; LL; G 3687, J 1586, P 133.

F. aurea Nutt.; T; PM; G 3823.

F. lapathifolia (Liebm.) Miq.; T; PM; G 3878.

F. velutina Humb. \& Bonpl. ex Willd.; T; PM; A 3748, P 303.

Pseudolmedia glabrata (Liebm.) C.C.Berg; T; PM; M 184.

P. spuria (Sw.) Griseb.; T; PM, LM; G 3831, 3832, J 1509, 1612, 1659, P 15 bis, 145, 309.

Trophis cuspidata Lundell; T; PM; G 3715, 3818.

T. mexicana (Liebm.) Bureau; T; PM; G 3834, J 1516.

MYRICACEAE (1/1)

Morella cerifera (L.) Small; S; PM; M 2384.

MYRTACEAE (6/12)

Calyptranthes chytraculia (L.) Sw. var. americana McVaugh; T; PM, LM; C 1384, G 3899, J 1449, 1495, M 1937, 2033, P 12 bis, 38.

* C. schiedeana O.Berg; T; PM; LM; C 965, 989, P 160, 276.

Calyptranthes sp.; T; LL; G 3786.

Eugenia sp. 1; T; PM, LM; A 228, C 1770.

Eugenia sp. 2; T; PM; G 3820, 3870.

Myrcia splendens (Sw.) DC.; S; PM; M 1617.

Myrcia sp.; T; PM; P 134, 220.

Psidium guineense Sw.; T; PM; M 2899.

Psidium sp.; T; PM; J 1453.

Syzygium jambos (L.) Alston; T; PM; C 1830, P 3.

Ugni myricoides(Kunth) O.Berg; T; UM; C 1140, 1277.

Myrtaceae 1; T; PM; A 3119, 3129.

NYCTAGINACEAE (1/1)

Neea psychotroides Donn.Sm.; T; LL; G 3801. 
Appendix. Continuation.

OCHNACEAE $(2 / 2)$

Ouratea sp.; T; PM; A 699, J 1957, P 14.

Sauvagesia erecta L.; $\mathrm{H}$ te; PM; M 2340, 2465, 2869.

OLEACEAE (1/1)

Osmanthus americanus (L.) Benth. \& Hook. f. ex A. Gray; T; PM, UM; A 870, C 1712, J 1680, 1699, P 70.

ONAGRACEAE $(2 / 3)$

Fuchsia arborescens Sims; T; PM, LM; G 3998, P 214, 271.

F. microphylla Kunth; S; LM, UM; A 176, 291, 3077, 3078, C 1101, 1102.

F. paniculata Lindl.; T; LM; A 379.

OROBANCHACEAE (2/2)

Conopholis alpina Liebm.; $\mathrm{H}$ te; UM; C 947, 1110.

* Lamourouxia xalapensis Kunth; S; LM, UM; C 816, 866, 867.

PAPAVERACEAE (1/2)

Bocconia arborea S.Watson; S; LM; A 356.

B. frutescens L.; T; PM; M 2448, 2939.

PASSIFLORACEAE (1/6)

* Passiflora complanata J.M.MacDougal; H cl; LL; G 3708, P 247.

* P. costaricensis Killip; H cl; LL; G 3678.

P. edulis Sims fo. edulis, $\mathrm{H}$ cl; PM; P 22.

P. hahnii (E.Fourn.) Mast.; H cl; PM, LM; A 324, M 1774.

P. helleri Peyr.; H cl; LL; J 1541.

* P. nelsonii Mast. \& Rose; H cl; PM; P 153.

PENTAPHYLACACEAE (2/2)

Cleyera integrifolia (Benth.) Choisy; T; LM, UM; A 200, 277, 300, 346, 464, 553, C 1222, J 1700, 1709, P 302.

Ternstroemia tepezapote Schltdl. \& Cham.; S T; PM, LM, UM; A 204, 210, 314, 463, 555,

C 859, 884, 945, 1117, 1141, 1218, 1420, J 1627, 1701, P 284, 301.

PHRYMACEAE (1/1)

Mimulus glabratus Kunth; H te; LM; C 1044.

PHYLLANTHACEAE (1/1)

Phyllanthus compressus Kunth; H te; PM; M 2906.

PHYLLONOMACEAE (1/1)

Phyllonoma laticuspis (Turcz.) Engl.; T; LM; C 844, P 78.

PHYTOLACCACEAE (1/2)

Phytolacca icosandra L.; H te; PM; M 874.

$P$. rivinoides Kunth \& C.D.Bouché; H te; LM; G 3997.

PICRAMNIACEAE (1/2)

Picramnia antidesma Sw.; T; PM; A 744, C 1820, P 264.

P. teapensis Tul.; T; PM, LM; G 3722, 3726, J 1572 bis, 1591.

PLANTAGINACEAE (3/3)

Lophospermum atrosanguineum Zucc.; H cl; PM, LM, UM; A 177, C 1360, G 3979.

Russelia sarmentosa Jacq.; H cl; LL, PM; M 1044, 1154, 1230, 2949.

Uroskinnera hirtiflora Hemsl.; S; LL, PM, UM; A 192, C 1795, M 1151, P 11, 292.

POLYGALACEAE (1/1)

Polygala paniculata L.; H te; PM; M 2868, 2907.

POLYGONACEAE $(2 / 3)$

Coccoloba hirtella Lundell; T; PM; G 3719, 3808, 3850, J 1535.

C. montana Standl.; T; LL, PM; J 1478, P 143, 266.

Muehlenbeckia tamnifolia (Kunth) Meisn.; H cl; UM; C 811, 1029.

PRIMULACEAE (5/16)

Ardisia compressa Kunth subsp. mexicana Oerst.; T; PM, LM; A 3161, C 1353.

A. liebmannii Oerst. subsp. liebmannii; T; PM; G 3720, J 1514.

A. paschalis Donn.Sm.; S; PM; M 1634.

A. revoluta Kunth; S; PM; M 1940.

A. tuerckheimii Donn.Sm.; S; LL; J 1480. 
Appendix. Continuation.

A. verapazensis Donn.Sm. subsp. verapazensis, T; PM, LM; C 1414, J 1491, 1644, M 2064, P 34, 267.

Deherainia matudae Lundell; T; PM; G 3769.

Gentlea penduliflora (A.DC.) Pipoly \& Ricketson; S T; LM, UM; A 320, 3074, C 868, 885, 968,

J 1681, 1716.

G. venosissima (Ruiz \& Pav.) Lundell; T; PM, LM; C 1768, 2179, J 1672, P 9, 285.

Myrsine coriacea (Sw.) R.Br. ex Roem. \& Schult. subsp. coriacea; T; LL, PM; C 2172, M 2228, 2379, 2983.

M. juergensenii (Mez) Ricketson \& Pipoly; T; PM, LM; A 238, C 840, 966, J 1670.

Parathesis donnell-smithii Mez; T; PM; G 3904, P 12, 101.

P. gracilis Lundell; T; PM; G 3847, J 1510.

P. melanosticta (Schltdl.) Hemsl.; S; PM, LM, UM; A 274, 344, C 888, 1097, 1188.

P. psychotrioides Lundell; T; PM; P 6.

P. tenuis Standl.; T; LM; A 353, C 964, 995, 1094, 1412.

PROTEACEAE (1/1)

Roupala montana Aubl.; T; PM, LM; C 1326, M 2586, P 45.

RANUNCULACEAE (1/1)

Clematis grossa Benth.; L; LL; M 2160.

RHAMNACEAE (2/3)

* Frangula capreifolia (Schltdl.) Grubov var. grandifolia (M.C.Johnst. \& L.A.Johnst.) A.Pool; T; PM, LM, UM; A 335, 359, 3091, C 1076, J 1630, M 1734, 2074.

* F. inconspicua A.Pool; T; LM; A 384, 568, 818, 3103, C 1958, 2181, P 159.

Gouania lupuloides (L.) Urb.; L; LL, PM; M 41, 1019.

ROSACEAE (4/10)

Lachemilla pectinata (Kunth) Rothm.; H te; UM; C 1039.

Photinia microcarpa Standl. subsp. hintonii J.B.Phipps; T; UM; A 340, J 1682, P 39.

* Prunus matudae Lundell; T; UM; A 307, C 858, 943, 1748.

P. rhamnoides Koehne; T; LM, UM; C 1114, 1150, J 1572.

* P. tuberculata Koehne; T; PM, LM, UM; A 208, 270, 449, 469, 3973, C 1143, 1331, 1717, 2178, J 1702, P 73.

Rubusglaucus Benth.; H cl; LM; C 1105.

* R. hadrocarpus Standl. \& Steyerm.; H cl; LM; C 1104.

R. sapidus Schltdl.; L; PM; A 3122.

R. schiedeanus Steud.; S; LM; A 293.

R. urticifolius Poir.; S cl te; LL, LM; A 393, C 1106, M 1178, 1258.

\section{RUBIACEAE (18/60)}

Arachnothryx buddleioides (Benth.) Planch.; S T; PM, LM; A 220, 350, C 841, J 2064.

A. capitellata (Hemsl.) Borhidi; T; LM; C 842.

A. gracilispica (Standl.) Borhidi; S; LL, PM; M 14, 175, 381.

A. heteranthera (Brandegee) Borhidi; T; LL, PM; G 3659, 3763.

A. purpurea (Lorence) Borhidi; T; LM; A 531.

A. scabra (Hemsl.) Borhidi; S T; PM, LM; A 218, C 847, 926, 929, 962, 1058, 1219, J 1588,

1622.

A. secundiflora (B.L.Rob.) Borhidi; S T; LL, PM, LM; G 3681, 3738, 3906, J 2065.

A. stachyoidea (Donn.Sm.) Borhidi; T; LL; J 1461.

A. villosa (Hemsl.) Borhidi; S T; LL; G 3756, M 405, 642, 772, P 252.

Arachnothryx sp.; T; PM; G 3836.

Coccocypselum cordifolium Nees \& Mart.; H te; LM; C 829, 2186 bis.

* C. guianense (Aubl.) K.Schum.; H cl te; PM; A 3084, M 189, 2937, 2648, P 293.

* Crusea calocephala DC.; H te; PM; M 2453, 2624.

* C. coccinea DC.; H te; LM, UM; A 178, 256, C 882.

* Deppea grandiflora Schltdl.; S T; LM, UM; A 458, C 942, 1731.

* D. umbellata Hemsl.; T; PM; G 3841.

Deppea sp.; S; PM; C 1806, P 147.

Diodella sarmentosa (Sw.) Bacigalupo \& E.L.Cabral; H te; LL; M 2137, 2281.

Faramea glandulosa Poepp.; T; LL, PM; M 514, 1316. 
Appendix. Continuation.

F. schultesii Standl.; T; PM, LM; A 529, 557, 3100, G 3967, M 606, 1662, P 10, 74, 137, 156. Hamelia patens Jacq.; T; LL; G 3751, J 1487.

* Hemidiodia ocymifolia (Willd. ex Roem. \& Schult.) K.Schum.; H te; PM; M 2936.

* Hoffmannia culminicola Standl. \& L.O.Williams; S; LM, UM; A 221, 289, 329, 450, 470, 535, C 1155.

H. discolor (Lem.) Hemsl.; H te; PM, LM; A 756, C 1340, G 3893, J 1531, M 171, 189, 369, 2978.

H. ixtlanensis Lorence; S; LL, PM; G 3793, M 42, 333, 1321, 1364, 2913.

H. nicotianifolia (M.Martens \& Galeotti) L.O.Williams; S; LL, PM, LM, UM; G 3665, 3721, 3784, 3792, 3816, 3835, J 1501, 1502, 1562, 1568, M 2120.

H. psychotriifolia (Benth.) Griseb.; T; LL; J 1563.

Hoffmannia sp.1; S; LM; G 3892.

Hoffmannia sp.2; S; PM; A 761, C 1341.

Hoffmannia sp.3; H ru te; PM; A 603, C 1386.

* Martensianthus albiflorus (Borhidi \& E. Martínez) Borhidi; S; LM; C 848, 1410, 2186.

Nertera granadensis (Mutis ex L.f.) Druce; H te; LM; A 187, C 1227.

Notopleura guadalupensis(DC.) C.M.Taylor ; S ep; LM; A 522.

N. hondurensis C.M.Taylor; H te; PM, LM; A 542, J 1518, P 289.

N. uliginosa (Sw.) Bremek.; $\mathrm{H}$ te; PM; J 1519.

Palicourea leucantha Donn.Sm.; T; LM; C 845.

P. macrantha Loes.; S; PM, LM; A 705, C 1409, P 206, 240.

* P. megalantha (Lorence) Lorence; T; PM, LM; A 541, J 1650, M 132.

P. padifolia (Willd. ex Roem \& Schult.) C.M.Taylor \& Lorence; T; LL, PM; A 601, 602, G 3810, 3960, J 1505, M 490, 1351.

* P. tetragona (Donn.Sm.) C.M.Taylor \& Lorence; T; PM; G 3729, 3768.

Posoqueria latifolia (Rudge) Roem. \& Schult.; T; LL, PM; C 1823, J 1448, M 648, P 76, 82, 95, 282.

Psychotria berteroana DC.; T; LL, PM, LM; A 532, J 1645, 1740, 1955, M 583, 840, 1000.

P. costivenia Griseb.; T; LL; G 3695.

P. elata (Sw.) Hammel; S T; LL, PM; A 567, 696, C 1348, J 1581, M 478, 1531, 2910, 2963.

P. galeottiana (M.Martens) C.M.Taylor \& Lorence; S T; PM, LM, UM; A 405, 430, 437, 438, 476, C 883, 973, 1025, 1091, 1225, G 3995, J 1628, 1683, M 1537.

P. graciliflora Benth.; T; PM; G 3712.

* P. grandis Sw.; T; LL; J 1468.

P. mexiae Standl.; T; LL, PM; G 3817, 3839, J 1469, 1504.

* P. mirandae C.W.Ham.; S; LL; G 3804, J 1473.

P. phanerandra (Standl. \& Steyerm.) Lorence; S T; PM; A 772, 773, C 1342, G 3676, 3776, J 1592, 1976, 2062, P 113.

P. poeppigiana Müll.Arg.; H te; LL, PM; J 1585, M 144, 706, 1424.

P. trichotoma M.Martens \& Galeotti; T; LL, PM, LM; A 763, C 1370, 1771, G 3663, 3894, J 1446, 1452, 1484, 1651, 2060, M 1310, 1424, 1935, P 16, 221.

Psychotria sp. 1; S; PM; J 1587.

Psychotria sp. 2; S T; PM, LM; A 543, 606, C 1417, G 3888, 3889, P 288.

Randia oaxacana Standl.; T; PM, LM; G 3900, J 1671.

R. pterocarpa Lorence \& Dwyer; T; LL; G 3669, 3690.

R. retroflexa Lorence \& M.Nee ; L; LL; G 3805.

R. xalapensis M.Martens \& Galeotti; T; LL, PM; G 3717, 3783.

Sabicea mexicana Wernham; S; LL, PM; M 1182, 1773, 2914, 2987.

Sommera arborescens Schltdl.; T; LL, PM, LM; A 747, C 1311, 1376, 1829, G 3716, 3825,

J 1496, 2063, M 161, 406, 2969, P 223, 304.

RUTACEAE (1/3)

Zanthoxylum melanostictum Schltdl. \& Cham.; T; PM; C 1772, P 43, 277.

Rutaceae 1; T; LL; J 1486.

Rutaceae 2; T; UM; J 1688.

SABIACEAE (1/1)

* Meliosma starkii E.Ramos; S T; LM; A 383, 406, 443, 559, C 970, 976, 999. 
Appendix. Continuation.

SALICACEAE (3/8)

Casearia corymbosa Kunth; S; PM; G 3826, M 2602.

C. sylvestris Sw.; T; PM; A 3121, C 1377, M 765, 2031.

Casearia sp.; T; PM; A 3128.

Pleuranthodendron lindenii (Turcz.) Sleumer; T; PM; A 3136, M 1983, P 144.

Xylosma oligandra Donn.Sm.; S T; PM; G 3713, 3760.

Xylosma sp.; T; PM; C 1828, J 1964.

Salicaceae 1; T; UM; C 1785.

Salicaceae 2; T; PM; A 3139.

SANTALACEAE (1/5)

* Phoradendron bolleanum (Seem.) Eichler; S ep; LM; C 1401, 1720.

* P. falciferum Kuijt; S ep; LM; C 1422, 1764.

Phoradendron sp.; S ep; PM; A 608, J 1669.

Santalaceae 1; S ep; LM; C 1721.

Santalaceae 2; S ep; LM; C 1950 bis.

SAPINDACEAE $(6 / 7)$

Allophylus psilospermus Radlk.; T; PM; G 3868.

Billia hippocastanum Peyr.; T; LM, UM; A 179, 432, 3079, C 865, 1193, J 1576.

Cupania sp.; T; PM; P 41.

Matayba oppositifolia (A.Rich.) Britton; T; PM, LM; A 564, G 3962, J 1668, M 1637, P 8, 52.

Paullinia costaricensis Radlk.; L; LL; G 3755.

P. pinnata L.; L; PM; J 1515, P 234.

Serjania mexicana (L.) Willd.; L; PM; P 127.

SAPOTACEAE (1/1)

Pouteria campechiana (Kunth) Baehni; T; PM; P 15, 202.

SCHLEGELIACEAE (1/1)

Gibsoniothamnus moldenkeanus (Standl.) L.O.Williams; S ep; LM; G 3907.

SOLANACEAE (8/33)

Cestrum fasciculatum (Schltdl.) Miers; S T; UM; C 899, G 3980.

C. miradorense Francey; T; LM; A 288, C 1022.

C. oblongifolium Schltdl.; T; PM; G 3732.

daltomata procumbens (Cav.) J.L.Gentry; H te; LM; C 1285.

Lycianthes ceratocalycia (Donn.Sm.) Bitter; S T; LM, UM; A 351, 514, J 2051.

L. heteroclita (Sendtn.) Bitter; S T; PM, LM; C 846, G 3830.

L. geminiflora (M.Martens \& Galeotti) Bitter; S T; PM, LM; C 1309, J 1629, P 114.

L. pilifera (Benth.) Bitter; S T; UM; A 468, 3068, C 1012, 1192, J 1692, 1720.

L. pilosissimmum (M.Martens \& Galeotti) Bitter; S T; LM, UM; A 416, 452, C 1078, 1186.

L. purpusii (Brandegee) Bitter; L; LL, PM; G 3764, 3781.

Lycianthes sp. 1; H te; LM; A 446.

Lycianthes sp. 2; T; PM; C 1364.

Physalis campanula Standl. \& Steyerm.; H te; LM; A 390.

Schraderanthus viscosus (Schrad.) Averett; H S; LM; A 357, 398.

Solandra maxima (Sessé \& Moc.) P.S.Green; L; LM; A 392, C 1019, 1070.

Solanum aligerum Schltdl.; S T; LM, UM; C 878, 936, 1016, 1100, 1264, 1796.

S. chiapasense K.E.Roe; T; LL; G 3704.

S. chrysotrichum Schltdl.; S; PM, LM; A 372, M 298, 563, 873.

S. ionidium Bitter; H cl; LM, UM; C 1051, 1073, 1189.

S. Ianceifolium Jacq.; $\mathrm{H}$ cl; PM; M 1441.

S. lepidotum Dunal; T; LL, PM; G 3740, 3840.

S. nigricans M.Martens \& Galeotti; T; LM, UM; A 255, C 896, 971, 1010, 1111, 1187, J 1721.

S. schlechtendalianum Walp.; S; LL, PM, LM; A 534, M 1360, 1878, 2270, 2310, 2896.

S. suaveolens Kunth \& C.D.Bouché; H cl; LL; J 1552.

S. torvum Sw.; S; PM; M 2485.

S. trizygum Bitter; H te; PM, LM; G 3819, J 1520, 1655.

S. volubile Sw.; L; PM; G 3814.

S. wendlandii Hook.f.; H cl; LM; C 1299. 
Appendix. Continuation.

Witheringia meiantha (Donn.Sm.) Hunz.; T; LM; A 378.

W. solanacea L'Hér.; H te; PM; M 1315, 1388, 1588, 2953, 2981.

Solanaceae $1 ; \mathrm{H}$ te; PM; A 746.

Solanaceae 2; S; PM; A 780.

Solanaceae 3; T; UM; A 3116.

SPIGELIACEAE (1/1)

Spigelia humboldtiana Cham. \& Schltdl.; H te; PM; M 2908.

STAPHYLEACEAE (1/3)

Turpinia occidentalis (Sw.) G.Don subsp. occidentalis, T; LL, PM; M 1513, P 231, 245, 254.

Turpinia sp. 1; T; UM; C 940, 1116.

Turpinia sp. 2; T; PM; J 1983.

STYRACACEAE (1/2)

Styrax glabrescens Benth.; T; UM; A 281.

S. warscewiczii Perkins; T; LM; A 371, C 1064.

SURIANACEAE (1/1)

Recchia simplicifolia T.Wendt \& E.J.Lott; T; LL; G 3789, J 1460.

SYMPLOCACEAE (1/5)

Symplocos austromexicana Almeda; S T; UM; C 1127, 1138, 1262.

* S johnsonii Standl.; T; PM; J 1511.

S. jurgensenii Hemsl.; T; PM, LM, UM; A 594, 806, 811, C 1063, 1403, 1794 bis.

S. pycnantha Hemsl.; T; LM; A 310, 467, C 803, 877, 938, 939, 1040, 1223, 1224, J 1704.

S. speciosa Hemsl.; T; UM; C 949, 1027, 1716, 1794.

THEACEAE (1/1)

Gordonia brandegeii H.Keng; T; PM, LM; A 3118, 3120.

THYMELAEACEAE (1/2)

Daphnopsis liebmannii Nevling; T; LM; A 472.

Daphnopsis sp.; T; PM; G 3809, 3873.

TICODENDRACEAE (1/1)

Ticodendron incognitum Gómez-Laur. \& L.D.Gómez; T; PM, LM; A 222, 3093, C 980, J 2049,

M 1667, P 33, 314.

ULMACEAE (1/1)

Ulmus mexicana (Liebm.) Planch.; T; PM; A 732, C 1804, G 3944.

URTICACEAE (5/13)

Boehmeria caudata Sw.; S; PM; M 2867.

Cecropia obtusifolia Bertol.; T; LL, PM; M 1040, P 84.

Myriocarpa sp.; T; LL; G 3791.

Pilea daguensis Killip; $\mathrm{H}$ te; PM; G 3844.

P. aff. imparifolia Wedd.; H ru; PM; J 1530.

P. pubescens Liebm.; H te; PM; G 3735.

P. purulensis Donn.Sm.; H te; LM; C 974.

Pilea sp.; H ru; PM; J 1744.

Urera corallina (Liebm.) Wedd.; T; LM; A 388, C 1741.

U. glabriuscula V.W.Steinm.; S; PM; G 3724.

U. killipiana Standl. \& Steyerm.; S; PM; M 2, 7.

Urticaceae 1; S; PM; A 596.

Urticaceae 2; T; PM; C 1390, 1802.

VERBENACEAE (2/2)

Lantana camara L.; H te; PM; M 2902.

Petrea volubilis L.; L; LL; G 3806.

VIOLACEAE (2/3)

Rinorea hummelii Sprague; T; LL; G 3807, J 1483.

Viola guatemalensis W.Becker; $\mathrm{H}$ te; UM; C 1038.

V. scandens Humb. \& Bonpl. ex Willd.; H cl te; LM, UM; C 854, 1006, 1103, 1121.

VITACEAE (3/5)

Cissus microcarpa Vahl; L; PM, LM, UM; C 1382, J 1533, M 206.

C. trianae Planch.; H cl; LM, UM; A 292, C 901, 1207. 
Appendix. Continuation.

* Parthenocissus quinquefolia (L.) Planch.; L; PM; M 1503, 1505.

Vitis popenoei J.L.Fenell; L; PM; M 340, 1853, P 146, 275.

V. tiliifolia Humb. \& Bonpl. ex Schult.; L; PM; P 86.

\section{Monocots}

ALSTROEMERIACEAE (1/3)

Bomarea acutifolia (Link \& Otto) Herb.; H cl; UM; C 1113, G 3981.

B. edulis (Tussac) Herb.; H cl; PM; P 243.

B. hirtella (Kunth) Herb.; L; LL; M 2245.

ARACEAE (6/27)

Anthurium cerropelonense Matuda; H ep ru; LM, UM; A 295, 296, 407, C 817, 851, 1018, G 3992.

A. longipeltatum Matuda; H ep te; PM, LM; A 584, C 1316, 1383, J 1657, 1751, 2059.

A. lucens Standl.; $\mathrm{H}$ te; PM, LM; A 584 bis, P 140.

A. microspadix Schott; $\mathrm{H}$ cl ep; PM; A 764, C 1343, G 3846, M 187.

* A. aff. nakamurae Matuda; $\mathrm{H}$ ep; LM; A 226.

A. scandens (Aubl.) Engl.; $\mathrm{H} \mathrm{cl}$; LM; A 798, C 1083.

A. schlechtendalii Kunth; H ep; PM; P 150, 308.

A. subovatum Matuda; H ep; LM; C 1001.

A. umbrosum Liebm.; H ep te; PM, LM; A 533, 585, 585 bis, 813, J 1577, 1658, 2057, P 24.

Anthurium sp. 1; $\mathrm{H}$ te; LM; A 402.

Anthurium sp. 2; $\mathrm{H}$ he; LM; A 561.

Anthurium sp. nov.; H ep; LM; A 373.

Monstera acuminata K.Koch; H ep; PM; M 1973.

M. deliciosa Liebm.; H ep; LM; A 576.

Philodendron advena Schott; H he; PM, LM; G 3851, J 1620.

P. hederaceum (Jacq.) Schott; H ep; LL, PM; M 667, 1644.

P. radiatum Schott; H ep; LL; M 1094.

P. standleyi Grayum; H he; PM; G 3865.

Philodendron sp.; $\mathrm{H}$ te; PM; A 770.

Spathiphyllum blandum Schott; $\mathrm{H}$ te; PM; M 1399, 1758.

S. cochlearispathum (Liebm.) Engl.; $\mathrm{H}$ te; PM; C 1349, J 1536, M 39.

S. phryniifolium Schott; H te; PM; M 1927.

Spathiphyllum sp.; H te; PM; A 741, 760, C 1375, G 3895, P 88.

Syngonium chiapense Matuda; H ep; PM; M 958.

S. podophyllum Schott; H ep; LL; M 1043.

S. sagittatum G.S.Bunting; $\mathrm{H}$ cl; LM; G 3903.

Xanthosoma robustum Schott; $\mathrm{H}$ te; PM; M 1728.

ARECACEAE (3/12)

Astrocaryum mexicanum Liebm. ex Mart.; P; LL; M 656.

Bactris mexicana Mart.; P; PM; M 599.

Chamaedorea elatior Mart.; P cl; PM; G 3778, J 1513, 1571, P 246.

C. elegans Mart.; P; LL, PM; G 3671, 3694, J 1465, 1570, M 1685.

C. liebmannii Mart.; P; PM, LM; A 246, 362, 363, 473, 815, C 927, 935, 969, 1087, 1308, 1777, J 2048, P 23.

C. oblongata Mart.; P; LL, PM; C 1815, G 3857, 3858, J 1464, 1466.

C. oreophila Mart.; P; PM, LM; A 423, C 961, 1020, 1049, 1050, G 3675.

C. pinnatifrons (Jacq.) Oerst.; P; LL, PM, LM; C 1366, G 3688, 3854, 3855, 3856, 3886, 3896, 3951, J 1456, 1508, M 1597, 1837, 2912.

C. rigida H.Wendl. ex Dammer; P; LM; A 224, 245, 360, 361, C 824, 832, 837, 916, 917, G 3966, 3968, J 1601.

C. sartorii Liebm.; P; PM; G 3670, 3691, J 1457, 1492, 1493, 1494.

C. tepejilote Liebm. ex Mart.; P; LL, PM; A 753, G 3668, J 1472, 1474, M 387.

C. woodsoniana L.H.Bailey; P; PM, LM; A 739, 752, C 1369, G 3891, 3898.

ASPARAGACEAE (2/3)

Dracaena americana Donn.Sm.; T; LL; J 1470. 
Appendix. Continuation.

Maianthemum macrophyllum (M.Martens \& Galeotti) LaFrankie; H ep; PM; J 1523, P 307. M. paniculatum (M.Martens \& Galeotti) LaFrankie; H ep te; PM, LM, UM; A 394, 428, 519, C 839, 946, 1085, 1086, 1119, J 1646, 1731, 2058.

BROMELIACEAE (6/18)

Catopsis paniculata E.Morren; H ep; PM; A 3085.

C. sessiliflora (Ruiz \& Pav.) Mez; H ep; PM; A 796.

Greigia van-hyningii L.B.Sm.; H te; LM; A 484.

Hohenbergia sp.; H ep; LM; J 1653.

Pitcairnia imbricata (Brongn.) Regel; H ru; LL; G 3748.

Pitcairnia sp.; H ep; LM; A 377.

Tillandsia butzii Mez; H ep; PM, LM; A 579, J 1752, P 65.

T. gymnobotrya Baker; H ep; LM; A 426, 498, 502, C 923 bis, 932 bis, 1953.

T. imperialis E.Morren ex Mez; H ep; LM; C 1077.

T. multicaulis Steud.; H ep; LM; C 1095.

T. punctulata Schltdl. \& Cham.; H ep; LM; A 374, 523, C 822, 933, 1726, 1952, 2180.

T. sierrajuarezensis Matuda; H ep; UM; A 196.

T. viridiflora (Beer) Baker; H ep; LM; A 242, C 919, G 3965.

Tillandsia sp. 1; H ep; PM; C 1371.

Tillandsia sp. 2; H ep; LM; A 550.

Tillandsia sp. 3; $\mathrm{H}$ ep; LM; A 581.

Werauhia vanhyningii (L.B.Sm.) J.R.Grant; H ep; LM; A 233, C 979, 994, 1069.

W. werckleana (Mez) J.R.Grant; H ep; LM; A 234, C 2187.

CANNACEAE (1/1)

Canna indica L.; $\mathrm{H}$ te; PM; M 140, 922.

COMMELINACEAE (3/3)

Gibasis oaxacana D.R.Hunt; H te; PM, LM; A 304, 328, 453, 754.

Tradescantia zanonia (L.) Sw.; H te; LL, PM; A 589, C 1345, 1350, G 3867, M 399.

Tripogandra serrulata (Vahl) Handlos; H te; PM; M 103, 2967.

COSTACEAE (1/3)

Costus pictus D.Don; H te; PM; M 359, 2107.

C. pulverulentus C.Presl; $\mathrm{H}$ te; LL; G 3709.

Costus sp.; H te; LM; A 592.

CYCLANTHACEAE (1/1)

Asplundia labela (R.E.Schult.) Harling; H cl; PM; G 3827, J 1454, 1748, M 1651, 2923, 2974, P 77.

CYPERACEAE (4/8)

Carex cortesii Liebm.; H ru; LM; A 345.

Rhynchospora aristata Boeckeler; H te; LM; A 515.

R. radicans (Schltdl. \& Cham.) H.Pfeiff.; H te; PM; M 2329, 2476.

Rhynchosporasp. 1; H te; LL; A 736.

Rhynchospora sp. 2; H te; LM; C 978.

Scleria bracteata Cav.; $\mathrm{H}$ te; PM; M 2984.

S. secans (L.) Urb.; H te; PM; M 1793, 2930.

Uncinia hamata (Sw.) Urb.; H te; PM; G 3813, J 1654, M 134.

DIOSCOREACEAE (1/2)

Dioscorea composita Hemsl.; H cl; PM; M 1874.

D. floribunda M.Martens \& Galeotti; H cl; PM; M 2471.

HAEMODORACEAE (1/1)

Xiphidium caeruleum Aubl.; H te; PM; M 1445, 1754, 2889, P 298.

HELICONIACEAE (1/1)

Heliconia uxpanapensis C.Gut.-Báez; H te; LL, PM; J 1488, M 530, 1352.

IRIDACEAE (3/5)

Neomarica variegata (M.Martens \& Galeotti) Henrich \& Goldblatt; H te; LL; G 3882.

Orthrosanthus monadelphus Ravenna; H te; UM; C 1035, G 3985.

* Sisyrinchium exalatum B.L.Rob. \& Greenm.; H te; UM; C 1034.

S. micranthum Cav.; $\mathrm{H}$ te; UM; A 787. 
Appendix. Continuation.

Sisyrinchium sp.; $\mathrm{H}$ te; UM; A 786.

JUNCACEAE (1/1)

Luzula denticulata Liebm.; H ru; LM; C 1115.

MARANTACEAE (2/3)

Calathea micans (L.Mathieu) Körn.; H te; PM; M 946.

* C. ovandensis Matuda; H te; LL; M 1216.

Stromanthe macrochlamys (Woodson \& Standl.) H.Kenn. \& Nicolson; H te; PM; G 3723.

ORCHIDACEAE (28/59)

* Anathallis platystylis (Schltr.) Pridgeon \& M.W.Chase; H ep; LM; A 232, 499, 804, C 828, 918, 1761.

Arpophyllum giganteum Hartw. ex Lindl.; H ep; PM, LM; A 565, 569, C 830, 986, J 1600, M 1670.

A. laxiflorum Pfitzer; H ep; LM; C 983.

A. medium Rchb.f.; H ep; LM; A 487.

Calanthe calanthoides (A.Rich. \& Galeotti) Hamer \& Garay; H te; LM, UM; C 1199, 1749, E 620, J 1691.

Camaridium cucullatum (Lindl.) M.A.Blanco; H ep; PM, LM; A 243, 481, 491, 574, 605, C 821, 1081, 1955, P 162, 280.

C. meleagris (Lindl.) M.A.Blanco; H ep; LM; A 575, C 1400.

C. pulchrum Schltr.; H ep; PM; M 2958, 2994, P 62.

Catasetum integerrimum Hook.; H ep; PM; G 3947.

Dichaea glauca (Sw.) Lindl.; H ep; PM, LM; C 985, P 148.

D. graminoides (Sw.) Lindl.; H ep; LM; J 1607.

D. muricatoides Hamer \& Garay; H ep; PM; A 587, P 50.

Dinema polybulbon (Sw.) Lindl.; H ep; LM; C 825.

日leanthus cynarocephalus (Rchb.f.) Rchb.f.; H te; LL, PM, LM; C 1080, M 976, 2956.

Epidendrum cardiophorum Schltr.; H ep; PM; J 1538.

E chlorocorymbos Schltr.; H ep; LL; P 190.

E mixtum Schltr.; H ep; PM, LM; A 478, 578, 797, C 831, 1763, 1949, P 281.

E pseudoramosum Schltr.; H ep; LM; C 987.

Gongora galeata (Lindl.) Rchb.f.; H ep; PM; G 3714, P 305.

Goodyera brachyceras (A.Rich. \& Galeotti) Garay \& G.A.Romero; H te; LM; C 1232 bis, J 1605.

Habenaria odontopetala Rchb.f.; H te; PM; J 1636.

Isochilus carnosiflorus Lindl.; $\mathrm{H}$ te; PM; C1345 bis.

I. latibracteatus A.Rich. \& Galeotti; H ep; PM; P 218.

Isochilus sp.; H ep; LM; A 421.

Jacquiniella leucomelana (Rchb.f.) Schltr.; H ep; LM; A 506, J 1608.

I teretifolia (Sw.) Britton \& P.Wilson; H ep; LM; C 833.

Lepanthes attenuata Salazar, Soto-Arenas \& O.Suárez; H ep; LM; A 479, 508, 510 bis, C 1226.

L. avis Rchb. f.; H ep; LM; A 509.

L. chiangii Salazar, Soto Arenas \& O.Suárez; H ep; LM; A 479 bis, 794.

L. erythroxantha Salazar \& Soto Arenas; H ep; LM; C 915, J 1950.

L. gabriellae Salazar \& Soto Arenas; H ep; LM; A 510, J 1603.

L. galeottiana Salazar \& Soto Arenas; H ep; LM; A 489, 490, 511, J 1609, 1951, 1952.

L. moorei C.Schweinf.; H ep; LM; C 915 bis, J 1604.

L. suarezii Salazar \& Soto Arenas; H ep; LM; A 507, J 1949.

L. yuvilensis Catling; H ep; LM; A 577.

Lepanthes sp. 1; H ep; LM; J 1947.

Lepanthes sp. 2; H ep; LM; J 1948.

Malaxis cf. excavata (Lindl.) Kuntze; H te; LM; C 1199 bis.

M. steyermarkii Correll; H te; LM; C 1232.

Maxillariella elatior (Rchb.f.) M.A.Blanco \& Carnevali; H te; LM; J 1573 bis.

M. variabilis (Bateman ex Lindl.) M.A.Blanco \& Carnevali; H ep; PM; P 67.

Mormodes maculata (Klotzsch) L.O.Williams var. maculata; H te; PM; E 689.

Oncidium incurvum Barker ex Lindl.; H ep; LM; A 495, J 2044.

O. sotoanum R.Jiménez \& Hágsater; H ep; PM; E 670, J 1498, P 287, 306. 
Appendix. Continuation.

Platythelys vaginata (Hook.) Garay; H ru; PM; G 3733.

Pleurothallis cardiothallis Rchb.f.; H ep; PM, LM; A 817, J 1652, 1675, P 139, 238.

Prescottia stachyodes(Sw.) Lindl.; H te; PM, LM, UM; A 709, 788, C 1951, G 3780, M 2016.

Prosthechea brassavolae (Rchb.f.) W.E.Higgins; H ep; LM; C 826, 1404, 1415.

P. rhynchophora (A.Rich. \& Galeotti) W.E.Higgins; H ep; PM, LM; A 571, 714, C 1416, P 61, 161.

P. varicosa (Bateman ex Lindl.) W.E.Higgins; H ep; LM, UM; A 3097, C 881, 948, 1399, 1713, G 3994.

P. vitellina (Lindl.) W.E.Higgins; H ep; LM, UM; A 409, 3075, C 1042, 1235, E 619, P 79.

Psilochilus aff. macrophyllus (Lindl.) Ames; $\mathrm{H}$ te; PM; P 295.

Rhynchostele ehrenbergii (Link, Klotzsch \& Otto) Soto Arenas \& Salazar; H ep; PM, LM, UM; A 615, C 1109, G 3993.

R. rossii (Lindl.) Soto Arenas \& Salazar; H ep; LM; A 494.

Stelis cobanensis (Schltr.) Pridgeon \& M.W.Chase; H ep; LM; C 1318.

S. oaxacana Solano; H ep; LM; A 572, C 1093, 1402.

S. pachyglossa (Lindl.) Pridgeon \& M.W.Chase; H ep; LM; A 486, 802, C 1761 bis, J 1602, 2042, P 315.

Vanilla planifolia Andrews; H ep; PM; M 2582.

Xylobium sulfurinum (Lem.) Schltr.; H te; PM; P 305 bis.

POACEAE (5/7)

Digitaria insularis (L.) Fedde; H te; PM; J 1458.

Homolepis aturensis (Kunth) Chase; H te; LL; M 2255.

Lasiacis procerrima (Hack.) Hitchc.; H te; LL; M 2204, 2395.

Panicum bulbosum Kunth; H te; LL, PM; M 64, 1214.

P. lepidulum Hitchc. \& Chase; H te; LL; M 2195, 2282.

Paspalum caespitosum Flüggé; H te; PM; M 2576.

Poaceae 1; H te; LM; C 1306.

SMILACACEAE $(1 / 7)$

Smilax domingensis Willd.; H cl; PM, LM, UM; A 315, 316, C 984, 1715, J 1611, 1679, 1708, M 1469, 1508.

S. glauca Walter; H cl; LL, PM; M 1207, 2427, 2563.

S. jalapensis Schltdl.; $\mathrm{H} \mathrm{cl}$; UM; C 900, J 1707.

S. regelii Killip \& C.V. Morton; L; PM; M 1398, 1867.

S. subpubescens A.DC.; L; PM; M 287, 1721, P 126.

S. velutina Killip \& C.V. Morton; L; PM; C 1391, M 618, 1439.

Smilax sp.; H cl; LM; C 1315.

ZINGIBERACEAE (1/3)

Renealmia alpinia (Rottb.) Maas; $\mathrm{H}$ te; PM; P 20.

R. aromatica (Aubl.) Griseb.; H te; PM; M 1722, 1822, 2888.

R. mexicana Klotzch ex Petersen; H te; LL, PM; M 432, 2102. 